Figure 1: These zircons (10.45-20.51 ct) from Ratanakiri, Cambodia, show the attractive blue colouration of heat-treated material from this locality. Photo by Mark H. Smith, Thai Lanka Trading Ltd Part. Bangkok, Thailand.

\title{
Blue Zircon from Ratanakiri, Cambodia
}

\author{
Manuela Zeug, Lutz Nasdala, Bhuwadol Wanthanachaisaeng, \\ Walter A. Balmer, Fernando Corfu and Manfred Wildner
}

ABSTRACT: Zircon from Ratanakiri Province, north-eastern Cambodia, is well known in the gem trade for its vivid blue colour that results from heat treatment. The untreated brown material turns blue under reducing conditions at $\sim 900-1,000^{\circ} \mathrm{C}$. Ratanakiri zircon is characterised by remarkably low contents of trace elements. In particular, the actinides have low concentrations (e.g. approximately $120 \mathrm{ppm} \mathrm{U}$ and $95 \mathrm{ppm}$ Th). Together with the very young age of the zircon $(<1$ million years [Ma]), this results in an extremely low self-irradiation dose, which in turn is in agreement with its non-radiation-damaged, nearly perfectly crystalline state. The heat treatment, therefore, does not result in detectable changes in the zircon's structural state. The cause of the blue colour, presumably related to a valence change upon heating in the reducing environment, is still under debate. The absorption of the treated Ratanakiri zircon is decidedly different from that of blue $\mathrm{U}^{4+}$-doped and blue $\mathrm{V}^{4+}$-doped synthetic $\mathrm{ZrSiO}_{4}$. Absorption spectra show a strongly pleochroic band at 18,200$13,000 \mathrm{~cm}^{-1}$ (corresponding to $\sim 550-770 \mathrm{~nm}$ wavelength) that is clearly responsible for the treated blue colour; however, its assignment remains unresolved.

The Journal of Gemmology, 36(2), 2018, pp. 112-132, http://dx.doi.org/10.15506/JoG.2018.36.2.112

- 2018 The Gemmological Association of Great Britain 



ircon has been used as a gem material for thousands of years. This is not least because of the mineral's high refractive index and optical dispersion. Transparent colourless zircon nearly approaches diamond in fire and brilliance, and therefore has been used as a diamond imitation for centuries. Colourless zircon is occasionally known in the gem market by its misnomer 'Matara (or Matura) diamond', named after the city of Matara on the southern coast of Sri Lanka (Roskin, 2003). In addition to being colourless, zircon occurs in a wide range of hues including slightly smoky or pale yellow ('jargoon' or 'jargon'), orange to reddish brown ('hyacinth' or 'jacinth'), yellowish to brownish green, dull dark brown to nearly black (often belonging to metamict varieties such as 'cyrtolith' or 'malacon') and purple and pink (Faulkner and Shigley, 1989; Nasdala et al., 2003; Kempe et al., 2016). Natural untreated blue zircon, however, is extremely rare. For example, small dipyramidal crystals of 'sky'-blue colour (occasionally with a greyish, greenish or purplish tint) are known from the San Vito quarry on the western slope of the Somma-Vesuvius volcanic complex in Italy (Russo and Punzo, 2004; see also Kempe et al., 2016).

Besides Sri Lanka, gem-quality zircon was, and still is, produced in Cambodia, Vietnam, Thailand, Myanmar, India, Pakistan, China, Russia, France, Tanzania, Madagascar, the USA, Canada, Australia and other countries (Faulkner and Shigley, 1989; Roskin, 2003; Watson, 2007; Smith and Balmer, 2009; Shigley et al., 2010; Chen et al., 2011; Sutherland et al., 2016). The reddish brown to brown zircon from Ratanakiri (or Ratanak Kiri), Cambodia, has become increasingly important in the gem trade, since it is known that this material turns into different shades of blue upon heat treatment, including a significant fraction that is vivid blue (Figure 1; Smith and Balmer, 2009). In addition to 'Starlite', the term 'Ratanakiri zircon' has developed into a common trade name for gem-quality blue zircon. The proliferation of 'Ratanakiri zircon' is somewhat comparable to the term 'Paraiba tourmaline', which has developed into a general trade name for vivid blue-to-green Cu-bearing tourmaline that is used regardless of a stone's geographical origin. Additional locations known to produce zircon that in some cases can be enhanced to (rather light) blue include Shan State in north-western Myanmar; Bang Kacha and Tok Prom near Chanthaburi, Thailand; Bo Phloi near Kanchanaburi, Thailand; and the Central Highlands of Vietnam (e.g. Roskin, 2003; Satitkune et al., 2013; Huong et al., 2016). However, none of these locations produces zircon that can be treated to such an intense, vivid blue colour as the Ratanakiri material. Here we present recent research regarding blue Ratanakiri zircon.

\section{BACKGROUND}

Zircon $\left(\mathrm{ZrSiO}_{4}\right)$ has a tetragonal structure (space group $\mathrm{IL}_{1} / \mathrm{amd}$ ) with a unit cell composed of four $\mathrm{SiO}_{4}{ }^{4-}$ and four $\mathrm{ZrO}_{8}{ }^{12-}$ groups (formula unit $\mathrm{Z}=4$ ). Non-formula cations incorporated in the zircon structure include trivalent rare-earth elements $\left(\mathrm{REE}^{3+}\right)$ as well as $\mathrm{Hf}^{4+}, \mathrm{Ti}^{4+}, \mathrm{Th}^{4+}$, $\mathrm{U}^{4+}, \mathrm{U}^{5+}, \mathrm{P}^{5+}, \mathrm{Nb}^{5+}$ and $\mathrm{Ta}^{5+}$ (Hoskin and Schaltegger, 2003; Kempe et al., 2016; and references therein). Although REEs are considered incompatible elements because of their large ionic radii, they commonly substitute in small amounts for $\mathrm{Zr}^{4+}$, which has dodecahedral coordination in the zircon lattice (Hanchar and van Westrenen, 2007). The incorporation of trivalent REE for tetravalent $\mathrm{Zr}$, however, requires charge compensation. This is mostly realised by combined incorporation of $\mathrm{REE}^{3+}$ along with a pentavalent ion, either $\mathrm{P}^{5+}\left(\right.$ for $\mathrm{Si}^{4+}$ ) or $\mathrm{Nb}^{5+} / \mathrm{Ta}^{5+}$ (for $\mathrm{Zr}^{4+}$; see Hoskin et al., 2000; Hoskin and Schaltegger, 2003; and references therein). Even though zircon has occasionally been reported to contain 10-30 wt.\% Hf (Ma and Rossman, 2005; Pérez-Soba et al., 2007; Van Lichtervelde et al., 2009) or up to 13 wt. \% U (Zamyatin et al., 2017), non-formula elements normally have low concentrations in this mineral. Other than $\mathrm{Hf}$ (with $\mathrm{HfO}_{2}$ typically in the range 0.6-2.0 wt.\%), all non-formula elements are well below the weightpercent level in gem-quality zircon.

Zircon is a common accessory mineral that occurs in many igneous and metamorphic rocks. Relatively large, gem-quality crystals grow predominantly in felsic pegmatites and more rarely in metasomatic rocks. Because of its hardness, remarkable physical stability and chemical resistance, zircon also is a common detrital component in sediments; hence this mineral often occurs in gravel deposits. Its susceptibility to weathering and other fluiddriven alteration, however, is appreciably increased upon the accumulation of radiation damage (e.g. Ewing et al., 2003; Hay and Dempster, 2009; Xu et al., 2012; Malusà et al., 2013). That is, alpha-decay events of $U$, and to a lesser extent Th (and their unstable daughter nuclei), result in structural damage, with the final, amorphous state being called metamict (Ewing, 1994). The accumulation of radiation damage in zircon is connected with a range of property changes, including a decrease in refractive index and birefringence (Sahama, 1981). Also, the density decreases from $\sim 4.7 \mathrm{~g} / \mathrm{cm}^{3}$ to well below $3.9 \mathrm{~g} / \mathrm{cm}^{3}$ (Holland and Gottfried, 1955). Highly radiation-damaged zircon (that nevertheless might have some gem quality areas, usually showing a green colour) is therefore often referred to as 'low zircon' in the gemmological community. 


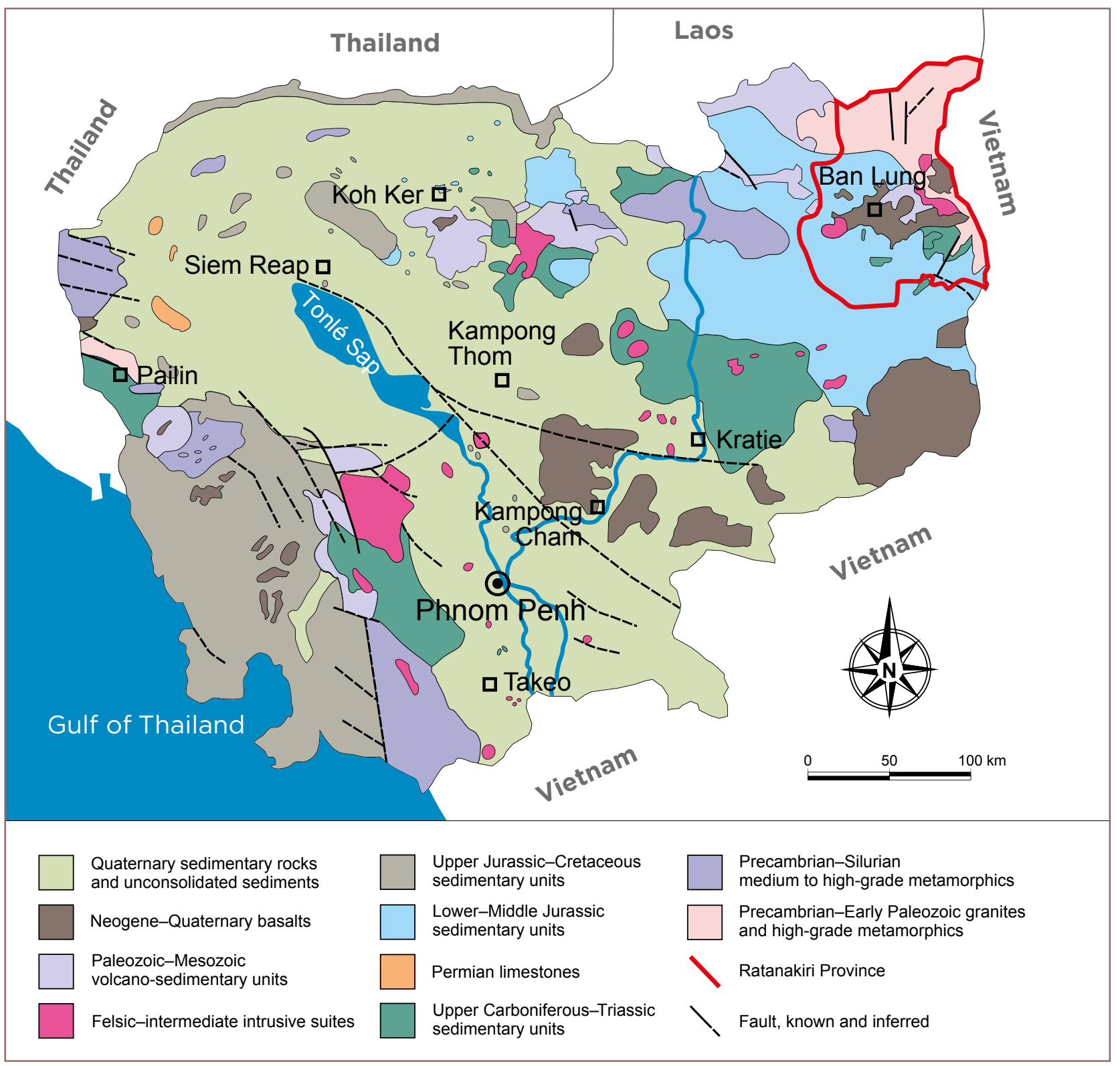

Figure 2: Ratanakiri Province, located in north-eastern Cambodia, is outlined in red on this simplified geological map of the country (modified after United Nations, 1993; Douglas et al., 2008). The zircon deposits are associated with the weathering of Neogene-Quaternary basaltic rocks (shown in dark brown).

The large variety of zircon colours depends on the content of transition metals and radiation-induced colour centres (Burns, 1993; Anderson and Payne, 1998; Nasdala et al., 2003), and might also involve crystalfield or charge-transfer transitions (Klinger et al., 2012; Kempe et al., 2016). However, the causes of most zircon colours remain unclear, or at least seem controversial to date. The only comprehensive summary of the literature, along with original spectroscopic results, was recently published by Kempe et al. (2016). The trace-elementrelated interpretations of colour causes proposed by these authors, however, remain unsupported as they did not present chemical data for their samples.
It should be added that doped synthetic $\mathrm{ZrSiO}_{4}$ of various colouration is used as high-temperature stable and chemically inert pigments. These include, for instance, yellow $\mathrm{Pr}^{3+}$-doped $\mathrm{ZrSiO}_{4}$ (Stiebler et al., 1992; Del Nero et al., 2004), 'lemon'-yellow $\mathrm{Tb}^{3+}$-doped $\mathrm{ZrSiO}_{4}$ (Kar et al., 2004), blue $\mathrm{V}^{4+}$-doped $\mathrm{ZrSiO}_{4}$ (Demiray et al., 1970; Niesert et al., 2002; Pyon et al., 2011) and pink-to-red Fe-doped $\mathrm{ZrSiO}_{4}$ (Cappelletti et al., 2005). It is, however, well known that the colours of natural zircon have different causes than those of the synthetic pigments, the latter of which contain dopant levels several orders of magnitude above the concentrations of the same elements in natural zircon. 


\section{ZIRCON MINING IN RATANAKIRI}

\section{Geological Setting}

Ratanakiri is the north-easternmost province of Cambodia. Here, zircon crystals are found in numerous alluvial deposits that formed from the weathering of Cenozoic (Neogene-Quaternary) basaltic rocks. The Ratanakiri volcanic province belongs to the Indochina Cratonic Terrane that covers eastern Thailand, Laos, Cambodia and southern Vietnam. The development of the Ratanakiri volcanic province heralds the start of the collision of the Eurasian and Indian continents during the Himalayan orogeny (55-45 Ma ago; Gibbons et al., 2015). Extensive volcanic activity occurred much later along reactivated crustal boundaries around the Pliocene-Pleistocene boundary spanning 4.3-0.8 Ma ago (Rangin et al., 1995). The Cenozoic basalt magmatism changed from early tholeiitic flood basalts to scattered volcanic cones of alkaline composition (Hoang and Flower, 1998). Alkali basaltic rocks are considered to be the host of Ratanakiri zircon (Figure 2). During a number of eruptive events that were confined to intersections of strike-slip faults, zircon crystals were transported as xenocrysts in the alkaline magma from considerable depths to the earth's surface (Rangin et al., 1995; Balmer et al., 2009). Gem-bearing alluvial layers are presently scattered throughout the region, and they vary in thickness and depth below the surface.

\section{Mining}

Gem mining activities in Ratanakiri started in the mid-1930s (Saurin, 1957). At present, several zirconbearing areas with numerous small workings are active (e.g. Figure 3). Their number, however, fluctuates depending on the economic situation. For instance, many mining sites closed during the past few years in favour of developing rubber plantations, which presently are more profitable than zircon mining. Productive areas for zircon are located near Ban Lung and Bae Srak (a settlement located just a few kilometres south of Ban Lung), and further east and northeast toward the Tonlé San River, especially around Bo Keo (the latter being $25 \mathrm{~km}$ east of Ban Lung and about 30 $\mathrm{km}$ from the border with Vietnam on the east). Here, gem zircon occurs in two different types of basalt-related deposits. The first consists of basaltic and pyroclastic material that is completely weathered into laterite soil, from which miners can easily extract zircon crystals by hand. The second type constitutes undecomposed basaltic gravels, requiring the use of water cannons to break up the material in search of zircon (cf. Smith


Figure 3: (a) A miner brings up a bucket filled with gravelbearing soil at this zircon mine near Bo Keo, Ratanakiri, where shafts extend to 17 m depth. (b) Near Bo Loi, Ratanakiri, gravel panning is done in a small pool lined with a plastic tarp. (c) In addition to zircon, the washed material includes garnet, sapphire, quartz, ruby and spinel. (d) This reddish brown, euhedral zircon crystal is from Phnum Trom, Ratanakiri. Photos by Ralf Grunert (a, c) and L. Nasdala (b, d). 
and Balmer, 2009; Balmer et al., 2009; Wanthanachaisaeng et al., 2014).

The mining methods are quite diverse because the zircon-bearing layers of various thicknesses occur at different depths. In the north (e.g. near Bo Loi, $25 \mathrm{~km}$ northeast of Ban Lung), gravel layers can be at fairly shallow depths; in some cases, they are even mineable in small open pits. Near Bo Keo and Phnum Trom (Bo Keo area), by contrast, miners must dig shafts up to 17 $\mathrm{m}$ deep into the red soil. These shafts typically are less than $1 \mathrm{~m}$ in diameter and have no reinforcement at all; just simple footsteps are dug into the side walls. At the bottom of the shaft, small horizontal tunnels are dug into the gravels. The miners face the constant danger of collapsing material. Buckets containing gravel and soil material are hoisted to the surface using manual winches (Figure 3a). Zircon and other heavy minerals are extracted by either dry hand-picking or pan-washing. In dry areas, washing may be done in small water-filled pits lined with plastic tarps (Figure $3 \mathrm{~b}$ ). Associated minerals found with the zircon include garnet, sapphire, quartz, ruby and spinel (Figure 3c).

Ratanakiri zircon is predominantly brown, often with a reddish or sometimes yellowish secondary hue; pale stones occur only occasionally. The shape of the zircon pieces varies considerably, ranging from completely rounded grains to perfectly euhedral crystals of predominantly short-prismatic habit (Figure 3d). Most, however, consist of moderately rounded, broken pieces that occasionally show crystal faces. Some of them have resorption features that might be due to transport in the basaltic magma (Balmer et al., 2009; Smith and Balmer, 2009).

\section{Colour Enhancement}

The brown zircon starting material is turned blue (Figure 4) by a simple heating process. The heat treatment takes place under reducing conditions at $900-1,000^{\circ} \mathrm{C}$ for one to a few hours (Smith and Balmer, 2009). The brown zircon (Figure 5a) is put into an alumina crucible (Figure 5b) that is sealed with a refractory clayey material (Figure 5c,d). The crucible is then enclosed in a larger crucible, which is sealed in the same manner. This assemblage is then placed in a charcoal furnace (Figure 5e) and covered with plenty of charcoal to achieve reducing conditions in an atmosphere of carbon monoxide and nitrogen. Obtaining the right temperature and atmosphere is a matter of experience; local gem treaters know the correct amount and type of charcoal to be used (for instance, charcoal made from mangrove wood works well). After two to three hours of heating, the crucible is opened and the still-hot zircon pieces initially appear colourless (Figure 5f). Only upon slow cooling do the zircon specimens develop the blue colour (Figure 5g,h).

The blue colouration of Ratanakiri zircon is long-term stable both in 'regular' daylight and in the dark; however, it shows a pronounced tenebrescence to both long- and short-wave UV radiation. Tenebrescence (i.e. reversible photochromism) is not a rare phenomenon in gems, and it has been occasionally observed for different colours and irradiations of zircon (McClure, 2011; Suthiyuth, 2014). The blue colour of Ratanakiri zircon changes to an unstable muddy greyish brown upon irradiation with long-wave UV radiation (including strong direct sunlight). The colour change appears to be fairly stable in the dark but reverses fairly soon after the sample is exposed to visible light without a UV component (Koivula and Misiorowski, 1986; Renfro, 2016).

Figure 4: These zircon samples from Ratanakiri (0.3-5.1 g)

include two untreated brown crystals and three blue specimens that were heat treated at $\sim 1,000^{\circ} \mathrm{C}$ under reducing conditions for a few hours. Photo by M. Zeug.
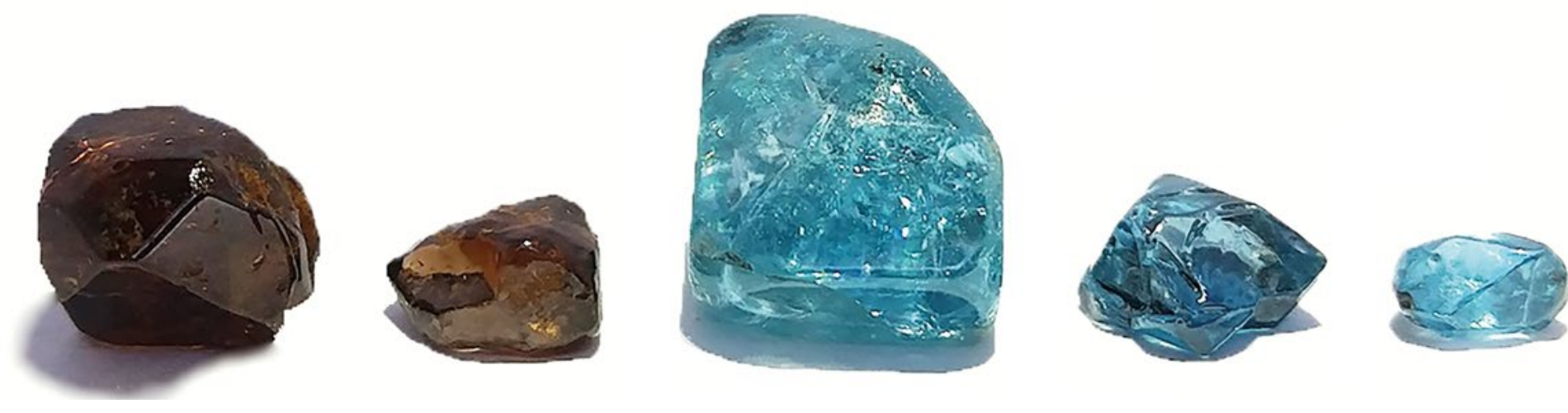

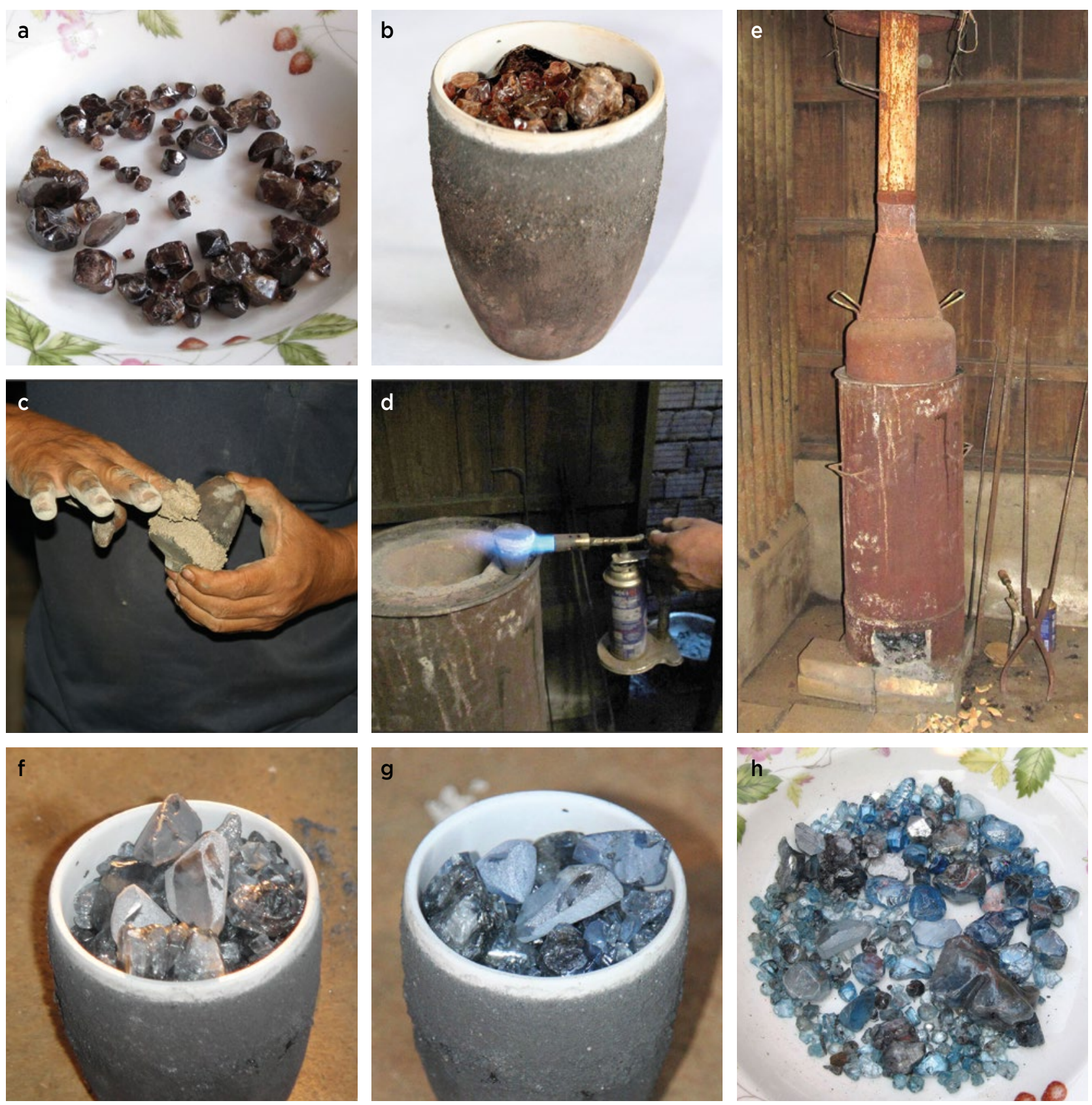

Figure 5: For the heat treatment of Ratanakiri zircon in a reducing environment, (a) the brown starting material is put into (b) an alumina crucible, and the lid is sealed with a refractory clayey material (c, d). Heat treatment at $\sim 900-1,000^{\circ} \mathrm{C}$ for $2-3 \mathrm{~h}$ is done in fairly simple ovens (e), with plenty of charcoal to ensure reducing conditions. After opening the crucible lid, the still-hot zircon material appears rather colourless (f), but becomes increasingly blue upon cooling $(g)$. A good fraction of the heated zircon ( $h$ ) shows the typical vivid blue colour. Photos by L. Nasdala (a, d, e, h), Ralf Grunert (b, c, g) and Astrid Wittwer (f).

\section{MATERIALS AND METHODS}

Six gem-quality zircon specimens from Ratanakiri, Cambodia, ranging from 0.53 to $6.76 \mathrm{~g}$, were sliced in half so that one part could be subjected to heating experiments while the other was retained for reference. Additional gem specimens from Ratanakiri also were heated without being sliced. The untreated samples were brown to reddish brown, some with light brown zones; the largest specimen showed fairly narrow primary growth zoning (Figure 6).

For comparison, we also analysed synthetic $\mathrm{ZrSiO}_{4}$ crystals grown using Li-Mo flux techniques. These included (1) a batch of 0.5-0.8 mm 'sky'-blue $\mathrm{V}^{4+}$-doped $\mathrm{ZrSiO}_{4}$ (made available by Dr John M. Hanchar; for a description of the synthesis technique, see Hanchar et al., 2001); (2) one $\sim 3 \mathrm{~mm}$ short-prismatic crystal of purplish blue $\mathrm{U}^{4+}$-doped $\mathrm{ZrSiO}_{4}$ (see Chase and 
Osmer, 1966) provided by Dr George R. Rossman; and (3) various crystals of synthetic $\mathrm{ZrSiO}_{4}$ individually doped with Pr, Sm, Nd, Tm or Dy, made available by Dr Dominik Talla (see Lenz et al., 2015). Optical absorption spectroscopy was performed on the first two sample sets, and photoluminescence (PL) spectroscopy was done on the third set, using the instrumentation described below.

The two largest Ratanakiri zircon specimens that were sliced-reportedly from Phnum Trom near Bo Keo-were bought from a local dealer in Ban Lung and were slabbed in his shop. Cutting was done parallel to the longest dimension of the nearly euhedral crystals to yield a pair of plates with matching faces. In both cases, the c-axis was oriented almost parallel to the cutting plane. One half of each specimen was then heat treated in Ban Lung by the same dealer (e.g. Figure 6). The other four zircon specimens that were sliced were first crystallographically oriented at the University of Vienna on a Nonius Kappa charge-coupled device (CCD) four-circle single-crystal X-ray diffraction system. Ten frames were obtained with a step width of $2^{\circ}$ using Mo- $K_{\alpha}$ radiation. The samples were then cut in half along their c-axis using a diamond-coated tungsten wire. One half of each sample pair was subjected to heat treatment for two hours at $900^{\circ} \mathrm{C}$ in an electric oven, together with excess charcoal to ensure reducing conditions, whereas the other half was left in its original state. For all six samples, parallel-plane, doubly polished plates were prepared from both the heated slice and its untreated counterpart. After the completion of analyses, one blue zircon half was again heat treated, but this time under oxidising conditions at $1,000^{\circ} \mathrm{C}$ for three hours. Additional heating experiments were carried out on unsliced specimens under reducing conditions at $800^{\circ} \mathrm{C}, 900^{\circ} \mathrm{C}$ and $1,000^{\circ} \mathrm{C}$, and under oxidising conditions at $300^{\circ} \mathrm{C}, 600^{\circ} \mathrm{C}, 800^{\circ} \mathrm{C}$ and $1,000^{\circ} \mathrm{C}$. The samples were placed in a graphite crucible, which was heated at a rate of $10^{\circ} \mathrm{C}$ per minute to the designated temperature. After the three-hour annealing run, the furnace was switched off and the samples were allowed to cool down slowly. Those treated under reducing conditions were packed in charcoal, and those annealed under an oxidising atmosphere were simply heated in air.

Specific gravity values (here reported as mass density) were determined for the unheated halves of the two largest stones that were cut in Cambodia, as well as on the four other samples before they were sliced in half. All samples appeared more-or-less free of inclusions. The mass density values were determined by repeated weighing of the specimens in air and in distilled water (with a minute amount of detergent added to reduce surface tension).

Chemical analysis of major elements in the six samples, including both the untreated and annealed halves, was done by means of a Cameca SX 100 electron probe micro-analyser (EPMA) operated at 15 $\mathrm{kV}$ and $40 \mathrm{nA}$. The focal-spot diameter of the electron beam was $5 \mu \mathrm{m}$. The following synthetic and natural calibrant materials were used (lines analysed are shown in parentheses): $\mathrm{ZrSiO}_{4}\left(\mathrm{Si}-K_{\alpha} ; \mathrm{Zr}-L_{\alpha}\right)$, Hf metal (Hf$\left.M_{\alpha}\right), \mathrm{YPO}_{4}\left(\mathrm{Y}-L_{\alpha}\right)$, sanidine $\left(\mathrm{Al}-K_{\alpha}\right), \mathrm{ScVO}_{4}\left(\mathrm{Sc}-K_{\alpha}\right)$, U

Figure 6: These two slices were cut from a gem-quality zircon crystal from Phnum Trom (largest dimension $17 \mathrm{~mm}$ ). The samples were prepared as doubly polished plates (2.7 $\mathrm{mm}$ thick), and the half on the right was subjected to heat treatment whereas the one on the left remained in its initial state.

The untreated specimen shows strong zoning, which disappeared after heat treatment. Photo by Astrid Wittwer. 
metal $\left(\mathrm{U}-M_{\beta}\right)$, brabantite $\left(\mathrm{Th}-M_{\alpha}\right)$, titanite $\left(\mathrm{Ca}-K_{\alpha}\right)$, fluorapatite $\left(\mathrm{P}-K_{\alpha}\right)$, almandine $\left(\mathrm{Fe}-K_{\alpha}\right)$ and $\mathrm{YbPO}_{4}(\mathrm{Yb}-$ $L_{\alpha}$ ). Peak/background counting times varied between $20 / 10 \mathrm{~s}$ and $80 / 40 \mathrm{~s}$ (the latter for the actinides). The modified $\varphi(\rho z)$ routine of Merlet (1994) was used for matrix correction and data reduction. Additional experimental details pertaining to EPMA analysis are described elsewhere (Breiter et al., 2010; Škoda et al., 2015).

Trace elements in the six samples, again including both untreated and annealed halves, were analysed with a Finnigan Element XR high-resolution laser ablation inductively coupled plasma mass spectrometer (LA-ICPMS) system coupled to a GeoLas $193 \mathrm{~nm}$ excimer laser. The ablated material was transported to the ICP-MS using He carrier gas with a flow rate of $1.25 \mathrm{l} / \mathrm{min}$, with additional Ar make-up gas added after the ablation cell. Elements in high abundance were analysed in analogue mode, whereas trace elements were analysed using a digital pulse counting mode. External independent calibration was done using NIST glasses 610 and 612 (Pearce et al., 1997) and USGS standard BCR-2G (Jochum et al., 2005). The laser spot size was varied between $40 \mu \mathrm{m}$ (NIST glasses) and $59 \mu \mathrm{m}$ (BCR-2G and zircon samples), resulting in an energy density of approximately $5 \mathrm{~J} / \mathrm{cm}^{2}$. The laser repetition rate was 8 Hz. Data reduction was done using the Iolite software package (Paton et al., 2011). For more analytical details, see Dorais and Tubrett (2012).

The U-Pb age of Ratanakiri zircon was determined for three fragments by means of solution isotope dilution thermal ionisation mass spectrometry (ID-TIMS) analysis (Krogh, 1973). The $\mathrm{Pb}$ and U isotope compositions were measured with a Finnigan MAT 262 mass spectrometer. After being cleaned with nitric acid, water and acetone, and weighed on a microbalance, the fragments were transferred to a Krogh-type FEP container and dissolved in hydrofluoric acid at $195^{\circ} \mathrm{C}$ after adding a ${ }^{202} \mathrm{~Pb}-{ }^{205} \mathrm{~Pb}-$ ${ }^{235} \mathrm{U}$ spike. The spike composition was calibrated against synthetic ET100 solution (Condon et al., 2008) provided by the Earthtime initiative (www.earth-time.org). Further details of the analytical procedure are reported elsewhere (Corfu, 2004). All isotope ratios and ages were corrected for fractionation, spike and blank. The ${ }^{204} \mathrm{~Pb}$ method was applied to correct for initial common $\mathrm{Pb}$ (based on Stacey and Kramers, 1975). The data were corrected for ${ }^{230} \mathrm{Th}$ disequilibrium according to Schärer (1984) and assuming a Th/U ratio of 4 in the magma.

Unit-cell dimensions were determined on five small chips (three brown and two blue) with a Huber 5042 four-circle single-crystal X-ray diffraction system. Analyses were done using non-monochromatised Mo radiation from a sealed-tube source at $50 \mathrm{kV}$ and $30 \mathrm{~mA}$. Fitting was done as implemented in the SINGLE software (Angel and Finger, 2010), and analytical settings of Hejny et al. (2012) were used.

Raman and PL spectroscopy of the six sliced samples, including untreated and annealed halves, was performed at room temperature using a dispersive Horiba LabRAM HR Evolution spectrometer equipped with an Olympus BX Series optical microscope and an Si-based, Peltiercooled CCD detector. The analysed light was dispersed using a diffraction grating with 1,800 (Raman) or 600 (PL) grooves per millimetre. Raman spectra were excited with the $632.8 \mathrm{~nm}$ emission of an He-Ne laser, and PL spectra were obtained using the $473 \mathrm{~nm}$ emission of a diodepumped solid-state laser. In both cases, the laser power was $10 \mathrm{~mW}$ at the sample. The system was calibrated using the Rayleigh line and emission lines of a $\mathrm{Kr}$ lamp, resulting in a wavenumber accuracy of better than $0.5 \mathrm{~cm}^{-1}$. Band fitting was done after appropriate background correction, assuming Lorentzian-Gaussian band shapes. Calculated full widths at half-band maximum (FWHMs) were corrected for instrumental broadening using the empirical formula of Váczi (2014).

Optical absorption spectra in the visible to near-infrared range were obtained for all six samples in the two principal polarisations (i.e. $\mathrm{E} \perp \mathrm{c}$ and $\mathrm{E}|| \mathrm{c}$ ) in the spectral range $24,100-5,250 \mathrm{~cm}^{-1}$ (which roughly corresponds to 415-1,900 nm wavelength*). Analysis of the UV range was omitted because of the well-known tenebrescence

\footnotetext{
* In this article, optical absorption spectra and PL spectra are plotted and discussed on the wavenumber ( $\tilde{v})$ scale. The wavenumber is defined as the reciprocal of the wavelength $\lambda$; it is quoted in reciprocal centimetres (conversion $\tilde{v}\left[\mathrm{~cm}^{-1}\right]=$ $\left.10^{7} / \lambda[\mathrm{nm}]\right)$. The wavenumber scale is preferred when evaluating spectroscopic data because wavenumber values (but not the wavelengths) are proportional to the photon energy of the detected light. This makes possible reliable band fitting and direct comparison of important diagnostic features (e.g. FWHMs, band shapes and band asymmetries) across the entire spectral range. By contrast, spectra plotted on the wavelength scale are distorted in energy, with the blue and UV ranges being compressed and the red and NIR portions being stretched. This results in strongly distorted band shapes that will bias any band fitting. The authors understand that the wavelength scale is traditionally preferred among gemmologists for describing the UV, visible and NIR spectral ranges. For convenience, we therefore present all PL and optical absorption spectra with additional labels for the top abscissa axis showing the wavelength scale (in $\mathrm{nm}$ ), and wavenumber values in the text and figures are accompanied by their respective wavelength values in parentheses.
} 
of blue zircon (irradiation with UV light, as an analytical artefact, produces a colour change that would bias the spectra obtained). Spectra were recorded at room temperature using a Bruker IFS 66v/S Fourier-transform infrared spectrometer equipped with a mirror-optics IR-scope II microscope and a quartz beam splitter. A calcite Glan prism was used to polarise the light. Circular areas $200 \mu \mathrm{m}$ in diameter were analysed in transmission geometry. The following combinations of light sources and detectors were used: Xe-lamp source and $\mathrm{GaP}$ detector for the spectral range $24,100-20,000$ $\mathrm{cm}^{-1}$ (40 $\mathrm{cm}^{-1}$ spectral resolution; 1,024 scans), W-lamp source and Si detector for the range 20,000-10,000 $\mathrm{cm}^{-1}$ (20 $\mathrm{cm}^{-1}$ spectral resolution; 1,024 scans) and W-lamp source and Ge detector for the range 10,000-5,200 $\mathrm{cm}^{-1}$ (10 $\mathrm{cm}^{-1}$ spectral resolution; 512 scans). The final spectra therefore consisted of a combination of three sub-spectra that were aligned to match in absorbance if necessary.

\section{RESULTS AND DISCUSSION}

\section{General Description and Heat Treatment}

Many of the untreated brown Ratanakiri zircon specimens contained macroscopically visible dark impurities and/ or large cavities. The latter were partially filled with baddeleyite (identified by Raman spectroscopy) and other secondary phases (Figure 7a,b). In addition, fluid inclusions showing various appearances were commonly observed. Some of them were transparent and colourless (Figure 7c), and others were dark brown and apparently opaque (Figure $7 \mathrm{~d}$ ) or consisted of two-phase inclusions filled with liquid and gas (Figure 7e). The fluid phase was predominantly composed of $\mathrm{H}_{2} \mathrm{O}$ (broad, lowintensity Raman band in the $3,200-3,500 \mathrm{~cm}^{-1}$ range). Occasionally they contained $\mathrm{CO}_{2}$ gas bubbles (Figure 7e; doublet of narrow Raman bands at 1,285 and 1,388 $\mathrm{cm}^{-1}$ ). Many fluid inclusions were surrounded by a network of veinlets that appeared to be partially healed fissures (Figure 7c). Much more rarely, dark fluid inclusions sometimes were surrounded by a halo containing phases that obviously were derived from the inclusion itself (Figure 7d). The water-rich fluid phase in the halo occasionally contained hematite flakes (identified by Raman spectroscopy; see Figure 7d).

Mass density values of the six untreated samples averaged $4.674 \pm 0.005 \mathrm{~g} / \mathrm{cm}^{3}$. This corresponds well to published density values in the range of $4.63-4.72 \mathrm{~g} / \mathrm{cm}^{3}$ for non- to mildly radiation-damaged zircon from Sri Lanka (Vaz and Senftle, 1971; Murakami et al., 1991).
Before heat treatment, the specimens showed brown to reddish brown colour, occasionally with an orangey hue, and some displayed distinct colour zoning (Figures 6 and 7f). Heating under reducing conditions at $800^{\circ} \mathrm{C}$ created a very pale blue colour. After heating at $900^{\circ} \mathrm{C}$ or $1,000^{\circ} \mathrm{C}$ under reducing conditions, the zircon samples showed a rather intense blue colouration, but with some variation in the depth of colour (see Figure $5 \mathrm{~h}$ ). The blue colour was rather uniform within single stones; primary growth zoning became invisible after the heating process (Figure 6). Our observation of a more-or-less equally intense blue colour after heating at $900^{\circ} \mathrm{C}$ and $1,000^{\circ} \mathrm{C}$ is in some contrast to the results of earlier studies. Thongcham et al. (2010) found maximum colouration after heating at $900^{\circ} \mathrm{C}$, whereas at $1,000^{\circ} \mathrm{C}$ the colour was clearly paler. Laithummanoon and Wongkokua (2013), by contrast, produced a rather pale blue at $900^{\circ} \mathrm{C}$, whereas the richest colour was reached at $1,100^{\circ} \mathrm{C}$. Summarising all available data, we conclude that $900-1,000^{\circ} \mathrm{C}$ (Smith and Balmer, 2009) is the most promising temperature range for the creation of attractive blue colour in Ratanakiri zircon.

Heating of both the untreated brown and the heated blue zircon under oxidising conditions at $300^{\circ} \mathrm{C}$ resulted in significant but incomplete decolouration. This appears to be consistent with the results of Wanthanachaisaeng et al. (2014) and Siriaucharanon et al. (2017), who observed fading of the dark brown colour to nearly colourless at $400^{\circ} \mathrm{C}$, although after initially heating their samples under reducing conditions. We found in our experiments that after oxidised heating at $600^{\circ} \mathrm{C}$ and above, the zircon samples became colourless to pale orange, without further significant changes at $800^{\circ} \mathrm{C}$ and $1,000^{\circ} \mathrm{C}$.

We also did a series of 'alternative heating' experiments, in which the zircon specimens were subjected to multiple heat treatments at $1,000^{\circ} \mathrm{C}$ for three hours each: first in a reducing atmosphere, then under oxidising conditions, then again under a reducing atmosphere and so on. Heating in a reducing atmosphere resulted in blue, subsequent oxidised heating produced nearly colourless with an orange tinge, then the same shade of blue reappeared after heating under reducing conditions, etc. We were able to switch the blue colour on and off within the same specimen. In conclusion, the blue colouration can be restored, whereas there is no heat-treatment technique that recovers the initial brown to reddish brown colour. This indicates that the initial brown colour is likely caused by an irradiation-induced defect that anneals upon heat treatment. 

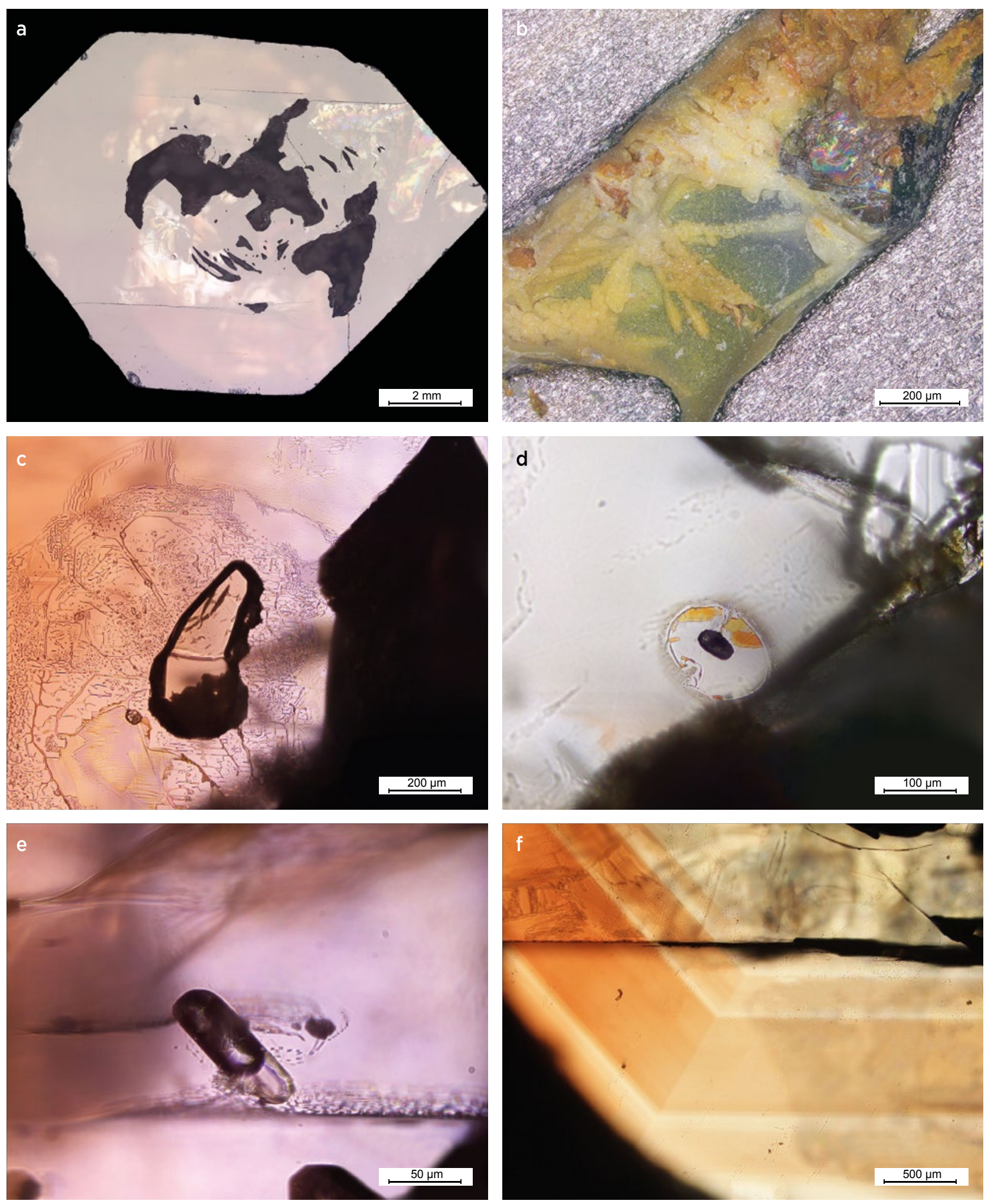

Figure 7: Various internal features are displayed by unheated Ratanakiri zircon. (a) Partially filled cavities are present inside a sliced zircon crystal. (b) The cavities are filled with yellowish baddeleyite and other unidentified alteration products. (c) This transparent fluid inclusion (mainly consisting of water) is surrounded by delicate patterns that trace fluid movement along fissures into the surrounding host. (d) An opaque inclusion of unknown composition is surrounded by a halo composed of water (clear area) and hematite (orange phase). (e) This fluid inclusion contains a large $\mathrm{CO}_{2}$ bubble. (f) Typical primary colour zoning is shown in an unheated brown zircon specimen. Photomicrographs by M. Zeug, in reflected light $(a, b)$ and plane-polarised transmitted light (c-f). 


\section{Chemical Composition}

Chemical data for Ratanakiri zircon determined by EPMA and LA-ICP-MS analyses are summarised in Table I. The samples generally had low contents of non-formula elements, below the $0.1 \mathrm{wt} \%$ level, with the only exception being $\mathrm{Hf}\left(\sim 0.7\right.$ wt. $\left.\% \mathrm{HfO}_{2}\right)$. This value is well within the typical range for zircon and hence it does not provide any particular hint as to the formation milieu (e.g. Belousova et al., 2002). Actinide and REE concentrations were slightly higher in zones and areas of darker brown colour, compared to paler brown regions. The actinides $U$ and Th had average concentrations of approximately $120 \mathrm{ppm}$ and $95 \mathrm{ppm}$, respectively. As is common for zircon, heavy REEs were enriched relative to the middle and light REEs (Table I; cf. Hoskin and Schaltegger, 2003; Hanchar and Westrenen, 2007). This also was evident in laser-induced PL spectra, which were dominated by strong emissions of $\mathrm{Dy}^{3+}$, along with lower-intensity emissions of $\mathrm{Sm}^{3+}, \mathrm{Pr}^{3+}, \mathrm{Tm}^{3+}$ and $\mathrm{Nd}^{3+}$ (Figure 8). The REE mass fractions of Ratanakiri zircon were slightly off the general trend for igneous zircon (Figure 9). We also observed a positive Ce anomaly $\left(\mathrm{Ce} / \mathrm{Ce}^{*}=42\right)$ but virtually no Eu anomaly (Eu/Eu* $=1.07)$. By contrast, most igneous zircon samples display both a positive Ce anomaly and a negative Eu anomaly (Hoskin and Schaltegger, 2003). Our observations indicate formation of Ratanakiri zircon under oxidising conditions, where Eu is mainly trivalent and Ce is mainly tetravalent (Hanchar et al., 2001). The absence of a negative Eu anomaly is not unusual; it has been observed in zircon crystals derived from kimberlites (Hoskin and Ireland, 2000) and syenite xenoliths associated with corundum (Hinton and Upton, 1991; Sutherland et al., 2002).

\section{Age Determination}

Results of seven ID-TIMS analyses of Ratanakiri zircon are presented in Table II. The mean ${ }^{206} \mathrm{~Pb} /{ }^{238} \mathrm{U}$ age was determined at $0.92 \pm 0.07 \mathrm{Ma}$ (error quoted at the $95 \%$ confidence level). This very young age appears consistent with the LA-ICP-MS results of Sutherland et al. (2015), who determined a mean ${ }^{206} \mathrm{~Pb} /{ }^{238} \mathrm{U}$ age of 0.83 $\pm 0.15 \mathrm{Ma}$ for three zircon inclusions in sapphires from Bo Loi, Ratanakiri. Those zircon inclusions, however, were genetically different from Ratanakiri gem zircon, as indicated by their much higher actinide concentrations of 299-1,114 ppm U and 150-1,270 ppm Th (Sutherland et al., 2015).

Table I: Average chemical composition of Ratanakiri zircon determined by EPMA and LA-ICP-MS.

\begin{tabular}{|c|c|c|c|c|c|c|c|}
\hline \multicolumn{2}{|c|}{ EPMA results $(n=172)^{a}$} & \multicolumn{6}{|c|}{ LA-ICP-MS results $(n=26)$} \\
\hline Oxide & $\begin{array}{c}\text { Concentration } \\
(w t . \%)^{b}\end{array}$ & Element & $\begin{array}{l}\text { Isotope } \\
\text { measured }\end{array}$ & $\begin{array}{l}\text { Concentration } \\
(\mathrm{ppm})^{c}\end{array}$ & Element & $\begin{array}{l}\text { Isotope } \\
\text { measured }\end{array}$ & $\begin{array}{l}\text { Concentration } \\
(\mathrm{ppm})^{c}\end{array}$ \\
\hline $\mathrm{SiO}_{2}$ & $32.6 \pm 0.2$ & $P$ & 31 & $73.5 \pm 15.6$ & $\mathrm{~Tb}$ & 159 & $4.37 \pm 2.37$ \\
\hline $\mathrm{ZrO}_{2}$ & $66.8 \pm 0.3$ & $\mathrm{Ti}$ & 49 & $6.37 \pm 2.46$ & Dy & 163 & $48.5 \pm 23.7$ \\
\hline $\mathrm{HfO}_{2}$ & $0.693 \pm 0.035$ & V & 51 & $\mathrm{nd}^{d}$ & $\mathrm{Ho}$ & 165 & $16.3 \pm 7.2$ \\
\hline $\mathrm{P}_{2} \mathrm{O}_{5}$ & $0.042 \pm 0.009$ & Y & 89 & $440 \pm 182$ & Er & 166 & $63.6 \pm 24.6$ \\
\hline \multirow[t]{8}{*}{ Total } & $100.2 \pm 0.4$ & $\mathrm{Nb}$ & 93 & $5.62 \pm 3.97$ & $\mathrm{Tm}$ & 169 & $12.1 \pm 4.1$ \\
\hline & & La & 139 & nd & $\mathrm{Yb}$ & 172 & $104 \pm 31$ \\
\hline & & $\mathrm{Ce}$ & 140 & $2.84 \pm 1.89$ & Lu & 175 & $16.6 \pm 4.2$ \\
\hline & & $\mathrm{Pr}$ & 141 & $0.07 \pm 0.05$ & $\mathrm{Hf}$ & 179 & $5,869 \pm 266$ \\
\hline & & $\mathrm{Nd}$ & 146 & $1.11 \pm 0.83$ & $\mathrm{~Pb}$ & 208 & nd \\
\hline & & Sm & 147 & $2.30 \pm 1.45$ & Th & 232 & $94.2 \pm 94.9$ \\
\hline & & $\mathrm{Eu}$ & 153 & $1.84 \pm 1.10$ & U & 238 & $119 \pm 68$ \\
\hline & & $\mathrm{Gd}$ & 157 & $11.9 \pm 6.7$ & & & \\
\hline
\end{tabular}

a $\mathrm{Al}_{2} \mathrm{O}_{3}, \mathrm{Sc}_{2} \mathrm{O}_{3}, \mathrm{CaO}, \mathrm{FeO}, \mathrm{Yb}_{2} \mathrm{O}_{3}, \cup_{2}$ and $\mathrm{ThO}_{2}$ were not detected or averages were below 0.005 wt.\%.

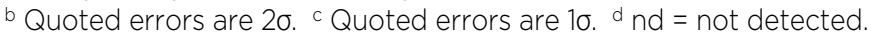




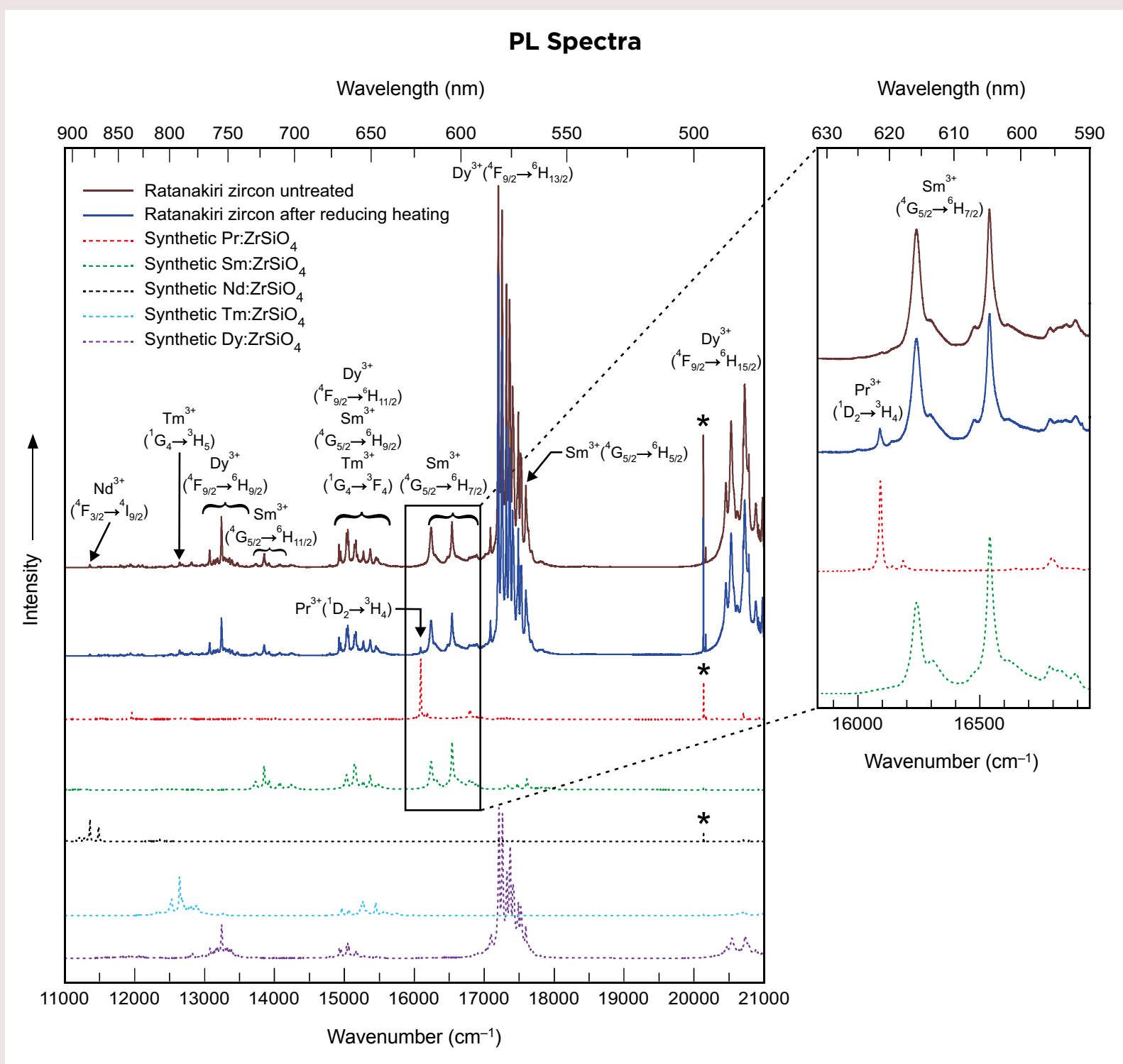

Figure 8: Representative PL spectra are shown for unheated and heat-treated Ratanakiri zircon, and compared to reference spectra of REE-doped synthetic $\mathrm{ZrSiO}_{4}$. Note that the ${ }^{1} \mathrm{D}_{2} \rightarrow$ ${ }^{3} \mathrm{H}_{4}$ transition of $\mathrm{Pr}^{3+}$ is only observed in the $\mathrm{PL}$ spectrum of heat-treated blue Ratanakiri zircon. Raman bands in the PL spectra are marked by asterisks. For assignment of PL lines see Gaft et al. (2000) and Lenz et al. (2015); for assignment of Raman bands see Nasdala et al. (1995; and references therein).

Figure 9: The average $\mathrm{Cl}$ chondrite-normalised REE concentrations in Ratanakiri zircon determined by LA-ICP-MS are plotted together with a shaded grey area, which shows the REE ranges of typical unaltered igneous zircon (graphically extracted from Figure 4 of Hoskin and Schaltegger, 2003).

\section{REE Content}

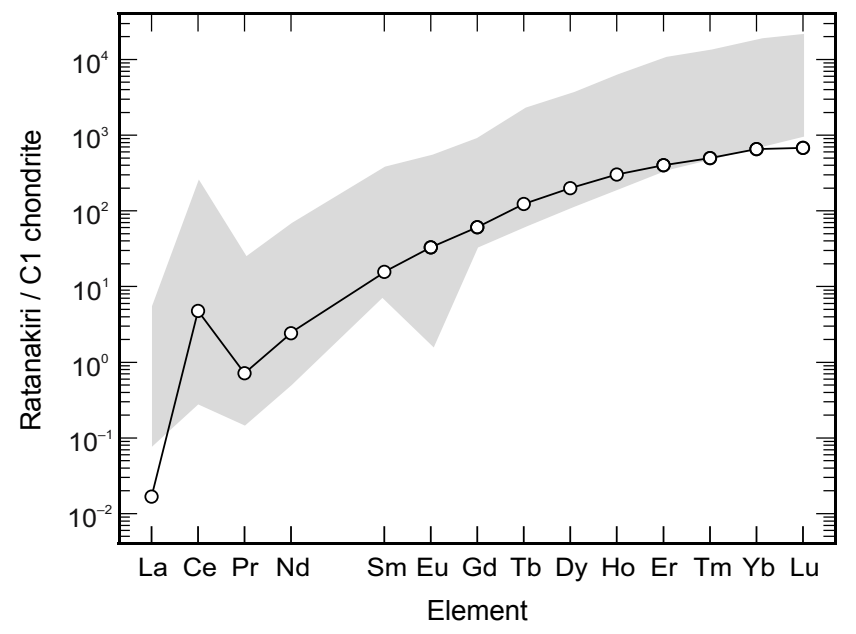


Table II: U-Pb geochronology data (ID-TIMS results) for Ratanakiri zircon.

\begin{tabular}{|c|c|c|c|c|c|c|c|c|c|c|}
\hline $\begin{array}{l}\text { Analysis } \\
\text { no. }\end{array}$ & $\begin{array}{c}\text { Weight } \\
(\mu \mathrm{g})\end{array}$ & $\begin{array}{c}\mathrm{Pb} \\
(\mathrm{ppm})\end{array}$ & $\underset{(p p m)}{U}$ & $\begin{array}{c}\text { Th } \\
\text { (ppm) }\end{array}$ & $\begin{array}{l}\mathrm{Pb}_{\text {com }}{ }^{\mathrm{a}} \\
(\mathrm{pg})\end{array}$ & $\begin{array}{l}{ }^{206} \mathrm{~Pb} / \\
{ }^{204} \mathrm{~Pb}^{6}\end{array}$ & $\left.{ }^{206} \mathrm{~Pb} /{ }^{238} \mathrm{U}\right)$ & $\begin{array}{c}{ }^{206} \mathrm{~Pb} / 238 \mathrm{U} \text { age } \\
\text { (Ma) }\end{array}$ & ${ }^{207} \mathrm{~Pb} /{ }^{235} \mathrm{U}$ & ${ }^{207} \mathrm{~Pb} /{ }^{206} \mathrm{~Pb}$ \\
\hline $389 / 10$ & 529 & 0.020 & 39.4 & 6.9 & 9.8 & 37.8 & $0.000160 \pm 0.000003$ & $1.03 \pm 0.02$ & $0.00124 \pm 0.00021$ & $0.0563 \pm 0.0100$ \\
\hline $389 / 10^{c}$ & - & 0.008 & 39.5 & 11.6 & 3.6 & 64.9 & $0.000143 \pm 0.000001$ & $0.92 \pm 0.01$ & $0.00093 \pm 0.00010$ & $0.0472 \pm 0.0051$ \\
\hline $391 / 1$ & 1166 & 0.004 & 31.9 & 11.6 & 1.8 & 191.1 & $0.000145 \pm 0.000000$ & $0.93 \pm 0.00$ & $0.00108 \pm 0.00004$ & $0.0539 \pm 0.0020$ \\
\hline $394 / 1$ & 585 & 0.031 & 39.3 & 54.3 & 16.4 & 29.0 & $0.000128 \pm 0.000004$ & $0.83 \pm 0.03$ & $0.00080 \pm 0.00025$ & $0.0451 \pm 0.0155$ \\
\hline $391 / 2$ & 840 & 0.014 & 46.4 & 20.5 & 8.5 & 56.6 & $0.000148 \pm 0.000001$ & $0.95 \pm 0.01$ & $0.00136 \pm 0.00008$ & $0.0668 \pm 0.0044$ \\
\hline $394 / 2$ & 948 & 0.022 & 58.1 & 24.1 & 14.9 & 47.9 & $0.000142 \pm 0.000002$ & $0.91 \pm 0.01$ & $0.00132 \pm 0.00010$ & $0.0676 \pm 0.0054$ \\
\hline $394 / 3$ & 833 & 0.038 & 40.0 & 1.1 & 29.1 & 27.1 & $0.000134 \pm 0.000005$ & $0.86 \pm 0.03$ & $0.00094 \pm 0.00030$ & $0.0510 \pm 0.0187$ \\
\hline
\end{tabular}

a $\mathrm{Pb}_{\text {com }}=$ total common $\mathrm{Pb}$ in sample (initial plus blank).

b Raw data, corrected for fractionation and spike.

c The solution for sample 389/10 was separated after dissolution and before chemical separation, for aliquot analysis

\section{Structural State}

The dimensions of the tetragonal unit cell were determined as $a_{0}=6.604 \pm 0.001 \AA$ and $c_{0}=5.979 \pm 0.001$ $\AA$, resulting in a unit cell volume of $260.73 \AA^{3}$. These values coincide (within errors) with the unit cell parameters of synthetic pure $\mathrm{ZrSiO}_{4}$ (Nasdala et al., 2002; Van Westrenen et al., 2004). The unit cell dimensions convert to an 'X-ray mass density' of $4.6699 \mathrm{~g} / \mathrm{cm}^{3}$, comparable to the average measured density of $4.674 \pm$ $0.005 \mathrm{~g} / \mathrm{cm}^{3}$. The FWHM of the $v_{3}\left(\mathrm{SiO}_{4}\right)$ Raman band, which is used to estimate the degree of self-irradiation damage in zircon (Nasdala et al., 1995), averaged $1.8 \pm$ $0.2 \mathrm{~cm}^{-1}$ (Figure 10a), indicative of a very high degree of crystallinity. The Raman spectrum of Ratanakiri zircon is, therefore, indistinguishable from that of synthetic pure $\mathrm{ZrSiO}_{4}$ (Nasdala et al., 2002).

Both X-ray and Raman results were identical within errors for unheated samples and their heat-treated analogues. This, and the conformity to synthetic pure $\mathrm{ZrSiO}_{4}$, indicates first that the generally low amounts of trace elements do not cause detectable deviation from the ideal zircon structure. Second, the absence of any detectable structural change upon annealing indicates that Ratanakiri zircon has not accumulated noticeable amounts of radiation damage. The alpha dose, calculated from the $\mathrm{U}-\mathrm{Pb}$ age and average $\mathrm{U}$ and $\mathrm{Th}$ concentrations, is $4 \times 10^{14} \alpha / \mathrm{g}$, which is well below the self-irradiation level of $\sim 5 \times 10^{16} \alpha / g$ that is known to cause initial spectroscopically detectable changes to zircon (Figure 10b; cf. Zhang et al., 2000; Nasdala et al., 2001).

Hence, it is not possible to unravel the heat treatment of Ratanakiri zircon by means of structural analysis. By contrast, there was a minor but interesting difference in the PL spectra: We found that the emission of treated Ratanakiri zircon always contained a low-intensity, narrow line at $16,090 \mathrm{~cm}^{-1}$ ( $621.5 \mathrm{~nm}$ wavelength; strong $\mathrm{E} \perp \mathrm{c}$ polarisation), whereas untreated specimens did not show this feature. It is assigned to the ${ }^{1} \mathrm{D}_{2} \rightarrow{ }^{3} \mathrm{H}_{4}$ electronic transition of $\mathrm{Pr}^{3+}$ (Figure 8; cf. Gaft et al., 2000). Its presence, however, cannot be used as a general indicator for the heat treatment of zircon, as the $\mathrm{Pr}^{3+}$ line has also been observed in untreated zircon specimens (e.g. the Sri Lankan reference zircon GZ7; Nasdala et al., research in progress).

\section{Optical Absorption Spectroscopy}

Optical absorption spectra are shown in Figure 11. Note again that the UV spectral region was not analysed in the present study because of the material's strong photochromism - that is, the fairly fast blue-to-brown colour change upon irradiation with, and hence analysis in, UV light.

The optical absorption spectrum of untreated Ratanakiri zircon was dominated by the following features: an intense absorption edge that extended from the UV into the blue range and down towards the NIR region; an intense broad absorption band near 19,800 $\mathrm{cm}^{-1}$ (505 nm wavelength); a rather weak, broad absorption band near $12,500 \mathrm{~cm}^{-1}$ (800 $\mathrm{nm}$ wavelength); and two groups of narrow absorption bands near $9,025 \mathrm{~cm}^{-1}(1,108.0 \mathrm{~nm}$ wavelength, with a shoulder at $\sim 9,190 \mathrm{~cm}^{-1}$ or $1,088.1$ $\mathrm{nm})$ and $6,665 \mathrm{~cm}^{-1}(1,500.4 \mathrm{~nm}$ wavelength) that are polarised with E $\perp c$ (Figure 11a). The reddish brown colour of the unheated zircon is due to the combination of the first two features listed above, which cause enhanced absorption in the blue-to-green range. The 
$\sim 19,800 \mathrm{~cm}^{-1}$ ( $\left.\sim 505 \mathrm{~nm}\right)$ band appears to be an analogue of the $510-515 \mathrm{~nm}$ absorption band described by Klinger et al. (2012). Those authors assigned reddish brown zircon colouration to a paramagnetic oxygen-hole centre nearest-neighbouring to an uncompensated $\mathrm{Y}^{3+}$ that substitutes for $\mathrm{Zr}^{4+}$. This assignment is supported by the disappearance of the $505-515 \mathrm{~nm}$ band upon heating: It has been known for a long time that electronor hole-related colour centres are irreversibly destroyed at fairly low temperatures of a few hundred degrees Celsius (Gastil et al., 1967; Fielding, 1970). Such hole centres may be generated slowly in zircon by radioactive self-irradiation (Rossman, 1981). If this is confirmed true, the very low self-irradiation dose experienced by Ratanakiri zircon might suggest that both the development of $\mathrm{Y}^{3+}$-related brown colouration and its saturation require fairly low irradiation levels. The two narrow absorptions in the spectral range below $10,000 \mathrm{~cm}^{-1}$ (i.e. above $1,000 \mathrm{~nm}$ wavelength) are due to $\mathrm{U}^{5+}$ (Vance and Mackey, 1974; Zhang et al., 2003). However, they do not contribute to the colouration, as these absorptions are in the NIR range.
After heating at $1,000^{\circ} \mathrm{C}$ in reducing conditions, the absorption edge and the bands at $\sim 19,800 \mathrm{~cm}^{-1}(\sim 505 \mathrm{~nm})$ and $\sim 12,500 \mathrm{~cm}^{-1}(\sim 800 \mathrm{~nm})$ were reduced significantly in intensity (Figure 11b). The spectra showed a new, strongly pleochroic $(\mathrm{E} \perp \mathrm{c})$ absorption band centred at $\sim 15,600 \mathrm{~cm}^{-1}$ ( 640 nm wavelength) with an FWHM of $>3,000 \mathrm{~cm}^{-1}$ ( $\geq 125 \mathrm{~nm}$ wavelength; Figure $\left.11 \mathrm{~b}\right)$. The absorption in the 18,200-13,000 $\mathrm{cm}^{-1}(\sim 550-770 \mathrm{~nm}$ wavelength) range results in a 'window' of reduced absorption in the blue to greenish blue region. Only a minor fraction of the uranium was reduced to $\mathrm{U}^{4+}$, whereas the majority remained in the pentavalent state. The appearance of tetravalent $U$ is seen in particular with $\mathrm{E} \perp \mathrm{c}$ polarisation by two narrow, low-intensity bands at $15,290 \mathrm{~cm}^{-1}$ (654.0 $\mathrm{nm}$ wavelength) and 14,480 $\mathrm{cm}^{-1}$ (690.6 $\mathrm{nm}$ wavelength). Due to their very small area integral compared to that of the broad $\sim 15,600 \mathrm{~cm}^{-1}$ $(\sim 640 \mathrm{~nm})$ band, the contribution of $\mathrm{U}^{4+}$ absorption is considered insignificant for blue zircon colouration.

After heating at $1,000^{\circ} \mathrm{C}$ in oxidising conditions, the $\sim 15,600 \mathrm{~cm}^{-1}(\sim 640 \mathrm{~nm})$ band disappeared completely (Figure 11c). It is worth noting that oxidised heating was

FWHM of $\mathrm{V}_{3}\left(\mathrm{SiO}_{4}\right)$ Raman Band
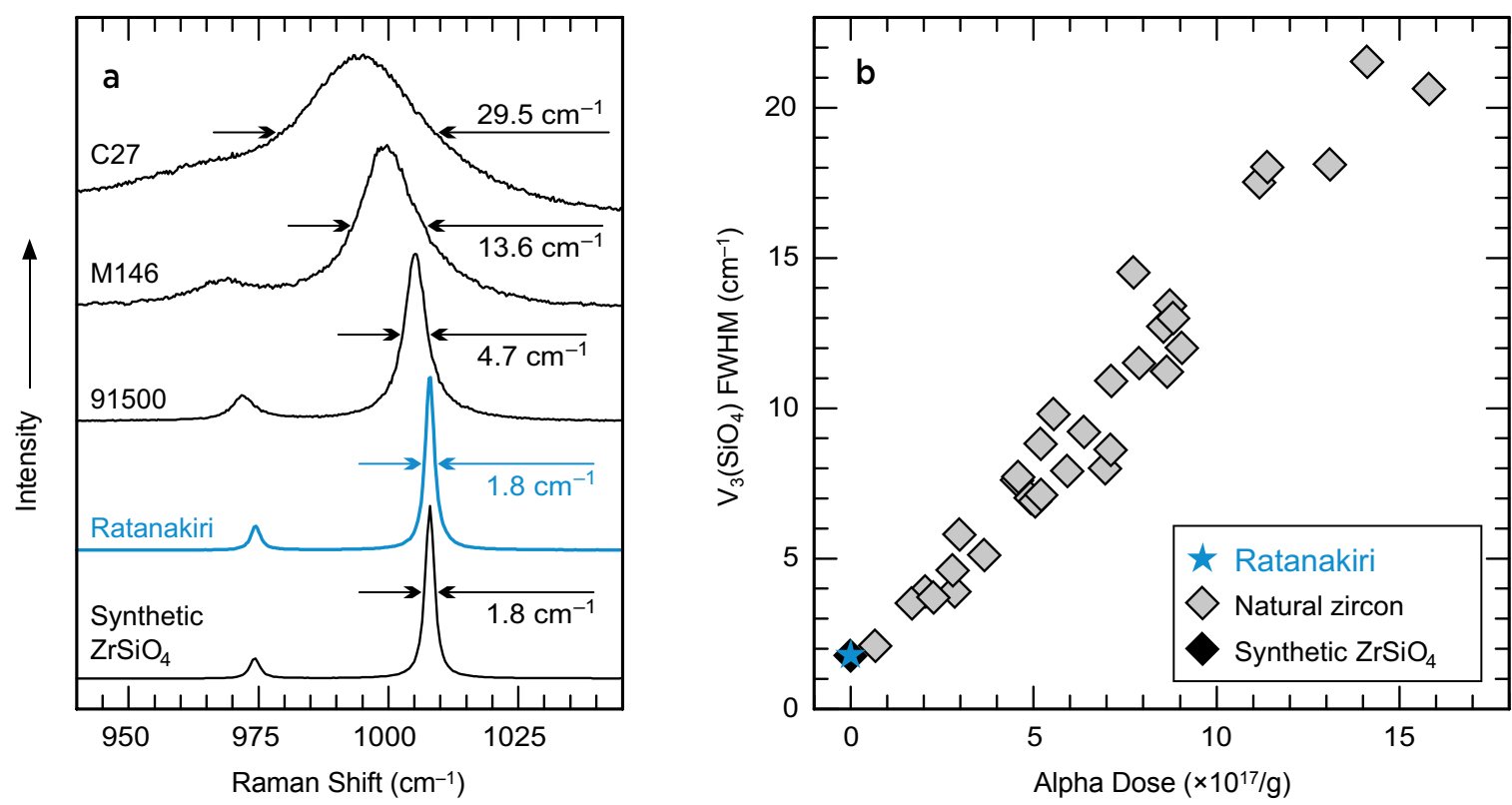

Figure 10: (a) The Raman spectrum $\left(\mathrm{SiO}_{4}\right.$ stretching region) of Ratanakiri zircon is shown in comparison with spectra of synthetic $\mathrm{ZrSiO}_{4}$ and three natural zircons with different degrees of radiation damage: sample 91500 from Kuehl Lake, Ontario, Canada (mildly damaged; see Wiedenbeck et al., 2004); and samples M146 (moderately damaged) and C27 (severely damaged), both from gem gravels in Ratnapura, Sri Lanka (for both, see Nasdala et al., 2004). (b) A plot of the FWHM of the $v_{3}\left(\mathrm{SiO}_{4}\right)$ Raman band near $1,000 \mathrm{~cm}^{-1}$ against the alpha dose includes data for Ratanakiri zircon, various samples of natural zircon (from Nasdala et al., 2001) and synthetic $\mathrm{ZrSiO}_{4}$. Both plots reveal that Ratanakiri zircon is spectroscopically indistinguishable from (perfectly crystalline) synthetic $\mathrm{ZrSiO}_{4}$, indicating that Ratanakiri zircon has accumulated extremely low amounts of radiation damage. 


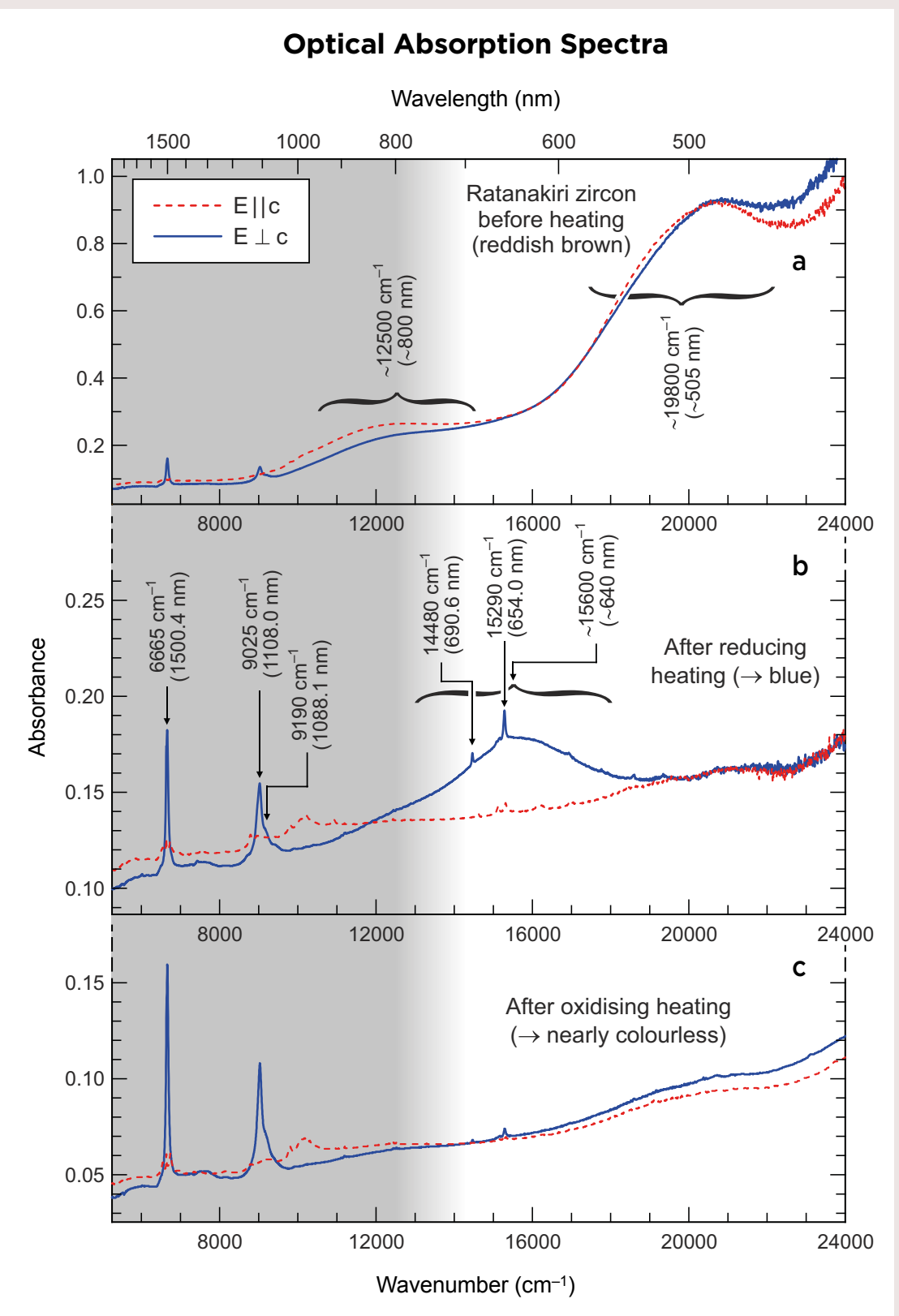

Figure 11: Polarised optical absorption spectra of Ratanakiri zircon (sample thickness $2.7 \mathrm{~mm}$ ) were obtained from the same specimen (a) before heating, and then after heat treatment at $1,000^{\circ} \mathrm{C}$ under (b) reducing and (c) oxidising conditions. The near-infrared range, invisible to the human eye, is shaded grey. After heating under reducing conditions, a broad absorption band in the 18,200-13,000 $\mathrm{cm}^{-1}$ $(\sim 550-770 \mathrm{~nm})$ region is observed with $E \perp c$. This band, of unknown attribution, results in a 'window' of reduced absorption in the blue to greenish blue range. Intense, sharp bands in the NIR region, especially at $6,665 \mathrm{~cm}^{-1}$ $(1,500.4 \mathrm{~nm})$ and $9,025 \mathrm{~cm}^{-1}$ $(1,108.0 \mathrm{~nm})$ are assigned to $\mathrm{U}^{5+}$-related centres; these bands, however, do not contribute to the colouration.

found to produce the same colouration (near-colourless) and absorption spectrum, independent of whether the starting material was unheated reddish brown or heat-treated blue. Similar to the results obtained for blue samples, the absorption edge and the $\sim 19,800 \mathrm{~cm}^{-1}$ $(\sim 505 \mathrm{~nm})$ and $\sim 12,500 \mathrm{~cm}^{-1}(\sim 800 \mathrm{~nm})$ bands were reduced significantly, with the absorption in the entire visible range being even slightly lower than in samples heated under reducing conditions. Compared to the spectrum of the blue zircon, the $\mathrm{U}^{4+}$ absorption features at $15,290 \mathrm{~cm}^{-1}(654.0 \mathrm{~nm})$ and $14,480 \mathrm{~cm}^{-1}(690.6 \mathrm{~nm})$ were appreciably lessened, in favour of a slight reincrease of the $\mathrm{U}^{5+}$ features at $9,025 \mathrm{~cm}^{-1}(1,108.0 \mathrm{~nm})$ and $6,665 \mathrm{~cm}^{-1}(1,500.4 \mathrm{~nm})$.

\section{Cause of the Blue Colouration}

The interpretation of the $\sim 15,600 \mathrm{~cm}^{-1}(\sim 640 \mathrm{~nm})$ band that causes blue colouration is problematic. This band appears quite similar in spectral position, width and polarisation to the $\sim 15,650 \mathrm{~cm}^{-1}(\sim 639 \mathrm{~nm})$ absorption band of $\mathrm{V}^{4+}$ in synthetic $\mathrm{ZrSiO}_{4}$ (Figure 12a; cf. Niesert et al., 2002). Nevertheless, the blue colour of Ratanakiri zircon cannot be assigned to $\mathrm{V}^{4+}$. First, the $\sim 6,900 \mathrm{~cm}^{-1}(\sim 1,450$ $\mathrm{nm}$ wavelength) absorption of $\mathrm{V}^{4+}$ with $\mathrm{E}|| \mathrm{c}$ is missing from the optical absorption spectra of blue Ratanakiri zircon. Second, the concentration of $\mathrm{V}$ in Ratanakiri zircon is below the LA-ICP-MS detection limit $(<0.04$ ppm), whereas blue $\mathrm{V}^{4+}$-doped $\mathrm{ZrSiO}_{4}$ has vanadium concentrations in the weight percent range (e.g. Niesert 


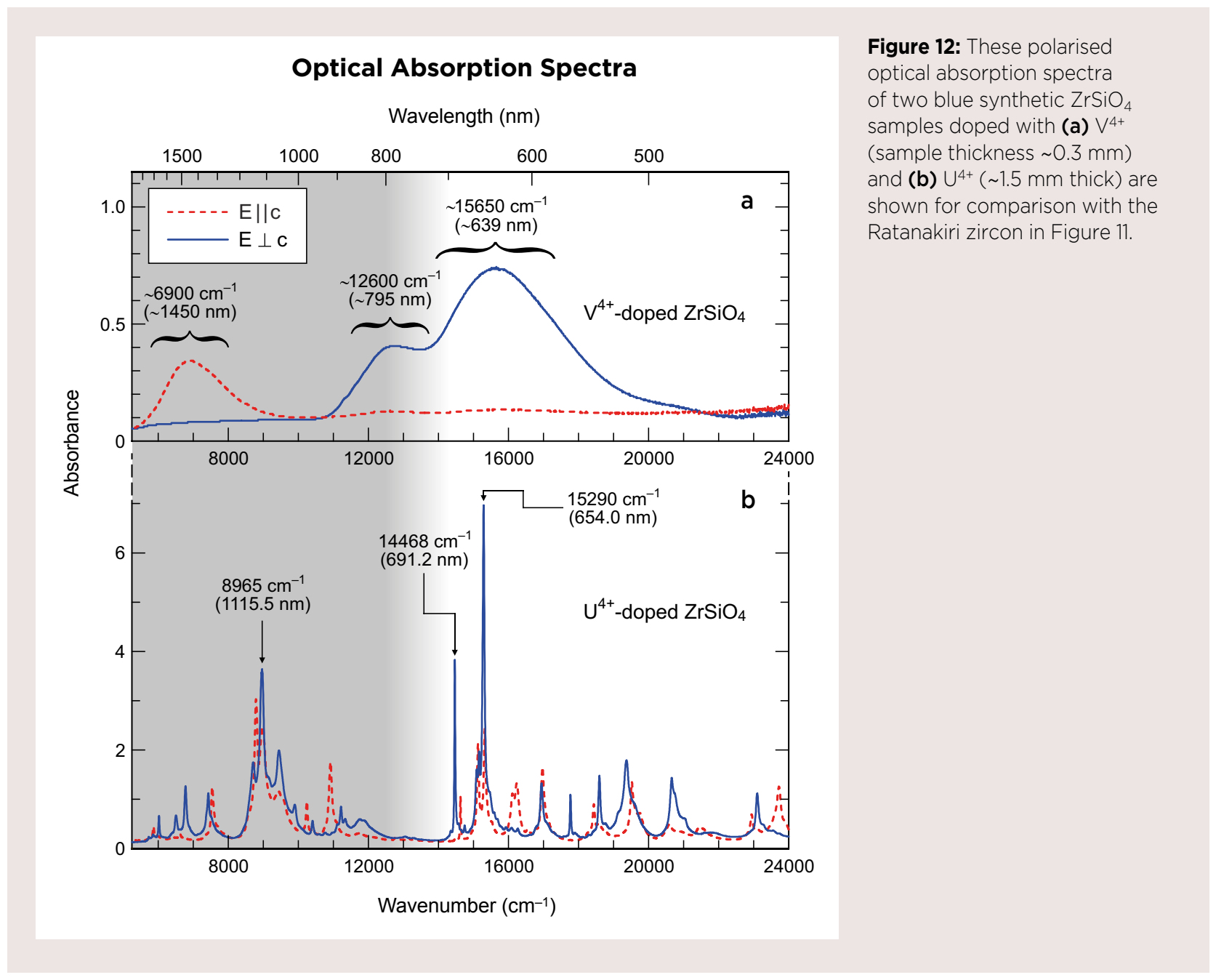

et al., 2002 reported $1.28 \mathrm{wt} \% \mathrm{~V}$ for their blue pigment). Third, if $\mathrm{V}^{4+}$ caused the colour of Ratanakiri zircon, a valence change of the $V$ needs to be assumed to explain the colour change upon oxidised heating. This is in contrast to the fact that blue $\mathrm{V}^{4+}$-doped $\mathrm{ZrSiO}_{4}$ is grown under oxidising conditions (Niesert et al., 2002). Also, we performed heat-treatment experiments on $\mathrm{V}^{4+}$-doped $\mathrm{ZrSiO}_{4}$ crystals, and neither reduced nor oxidised heating seemed to affect their blue colouration.

Another possible cause of the blue colour of zircon is the elevated presence of $\mathrm{U}^{4+}$. The absorption of this ion in the $\mathrm{ZrSiO}_{4}$ structure is characterised by numerous, strongly polarised lines (Richman et al., 1967), with the strongest absorptions in the red range. Together with the commonly present absorption edge that extends from the UV into the blue range, $\mathrm{U}^{4+}$ absorption might cause green zircon colouration (Kempe et al., 2016, and references therein), whereas $\mathrm{U}^{4+}$ alone causes blue. We had the opportunity to verify this by studying one of the historic synthetic $\mathrm{U}^{4+}$-doped $\mathrm{ZrSiO}_{4}$ crystals grown by Judith A. Osmer, now in the sample collection of
Dr George R. Rossman. Whereas Chase and Osmer (1966) described green U-doped zircon, the specimen loaned to us displayed blue colour with a weak purplish hue. The optical absorption spectra are shown in Figure 12b.

Previous authors (Wanthanachaisaeng et al., 2010; Satitkune et al., 2013) have assumed that the blue colour of Ratanakiri zircon might be assigned to a change in the oxidation state of uranium. This was questioned by Thongcham et al. (2010), who found that upon heating above $900^{\circ} \mathrm{C}$, the blue colour decreased whereas the narrow $\mathrm{U}^{4+}$ absorption still increased. Our optical absorption spectra of blue Ratanakiri zircon (Figure 11) show $\mathrm{U}^{4+}$ absorption lines of very low intensity. Despite the reducing conditions during heating, most of the $U$ remained in the pentavalent state. There was minor $\mathrm{U}^{5+} \rightarrow \mathrm{U}^{4+}$ transformation; this, however, was negligible compared to the observed change in colour. Another consideration questioning $U$ as the colour cause is that, of all zircons, the low-U Ratanakiri material is particularly susceptible to develop blue colour. One would expect that if $U$ caused blue colour, zircon containing 


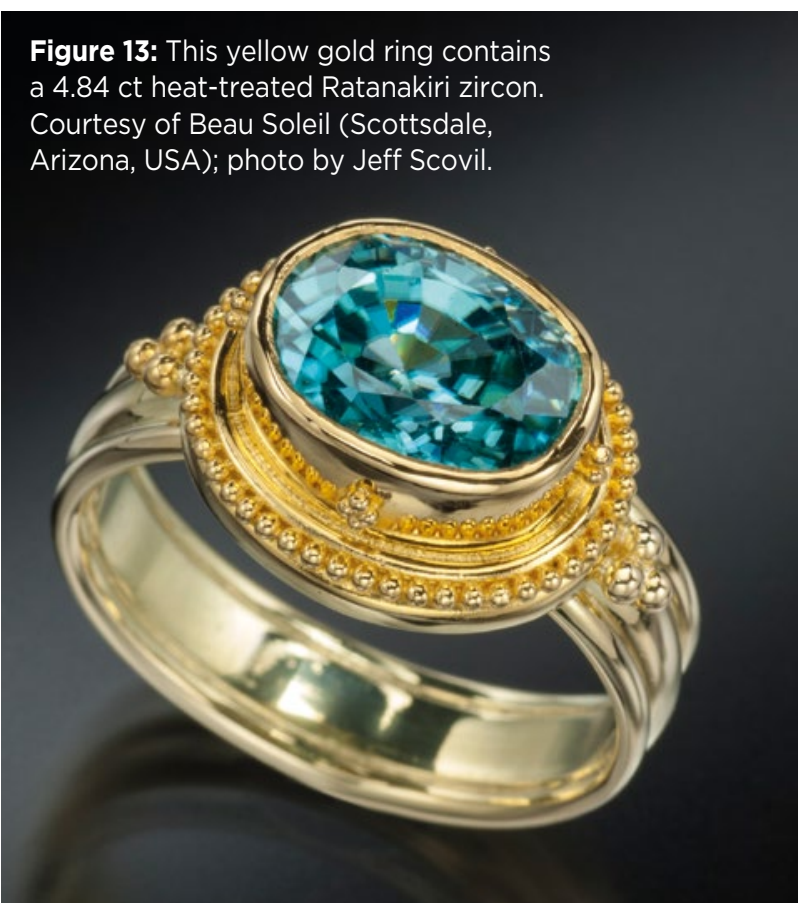

more U should show an even more intense blue. That, however, is not the case.

Another attempted assignment of the blue colour was published by Laithummanoon and Wongkokua (2013). They speculated that the blue colouration is due to a change in the oxidation state of $\mathrm{Tb}$ (i.e. $\mathrm{Tb}^{4+} \rightarrow \mathrm{Tb}^{3+}$ ) upon heating under reducing conditions. This was based on the two observations that the colour change was accompanied (1) by the disappearance of $\mathrm{Tb}^{4+}$ signals in electron paramagnetic resonance spectra and (2) by the concurrent appearance of a small absorption feature near $650 \mathrm{~nm}$. However, the $\sim 650 \mathrm{~nm}$ feature also was present in optical absorption spectra obtained by Laithummanoon and Wongkokua (2013) after oxidised heating at $600^{\circ} \mathrm{C}$ and $700^{\circ} \mathrm{C}$, which produced nearly colourless samples and questions the contribution of the $\sim 650 \mathrm{~nm}$ feature to zircon colouration. We assign the

\section{REFERENCES}

Anderson B.W. and Payne C.J., 1998. Absorption spectra of zircon. In R.K. Mitchell, Ed., The Spectroscope and Gemmology, GemStone Press, Woodstock, Vermont, USA, 194-202.

Angel R.J. and Finger L.W., 2010. SINGLE: A program to control single-crystal diffractometers. Journal of Applied Crystallography, 44(1), 247-251, http://dx.doi.org/10.1107/s0021889810042305.

Balmer W.A., Smith M.H., Sriprasert B. and Wanthanachaisaeng B., 2009. Ratanakiri, the legendary zircon province of Cambodia. European Gemmological Symposium, Berne, Switzerland, 5-7 June, 51-53. broad $\sim 650 \mathrm{~nm}$ band observed by Laithummanoon and Wongkokua (2013) to $\mathrm{U}^{4+}$ (cf. $15,290 \mathrm{~cm}^{-1}$ or $654.0 \mathrm{~nm}$ band in Figure 12b). Also, one should note that the electronic structure of $\mathrm{Tb}^{3+}$ shows a huge gap between $\sim 20,000$ and $6,000 \mathrm{~cm}^{-1}$ ( 500-1,667 nm wavelength; Dieke and Crosswhite, 1963; Couwenberg et al., 1998), which suggests that absorption of visible light is only possible in the blue range.

\section{CONCLUSIONS}

Zircon from Ratanakiri Province in north-eastern Cambodia is mined from secondary deposits associated with the weathering of alkali basaltic rocks. We determined a mean ${ }^{206} \mathrm{~Pb} /{ }^{238} \mathrm{U}$ age of $0.92 \pm 0.07 \mathrm{Ma}$ for the zircon. The unit cell dimensions and Raman data indicated a very high degree of crystallinity, which is consistent with the young age and the low concentration of actinides. Our samples also had consistently low contents of other non-formula elements (i.e. below the $0.1 \mathrm{wt} . \%$ level), with the only exception being $\mathrm{Hf}$ $\left(\sim 0.7\right.$ wt. $\% \mathrm{HfO}_{2}$, which falls within the typical range for zircon).

Ratanakiri zircon turns vivid blue (e.g. Figure 13) upon heat treatment under reducing conditions at $900-1,000^{\circ} \mathrm{C}$. Based on the new data presented here, the authors exclude several of the potential colour causes that have been proposed in the literature thus far. However, we are still unable to provide convincing explanations (1) for the blue colour of Ratanakiri zircon and (2) for why zircon from other localities is much less, or even not at all, susceptible to an analogous colour change. Even though we have demonstrated that the blue colour is due to a broad, strongly polarised absorption band $(\mathrm{E} \perp \mathrm{c})$ in the red-to-yellow range (centred at $\sim 15,600 \mathrm{~cm}^{-1}$, or $\sim 640 \mathrm{~nm}$ wavelength), a definitive assignment of this band remains enigmatic.

Belousova E., Griffin W., O’Reilly S.Y. and Fisher N., 2002. Igneous zircon: Trace element composition as an indicator of source rock type. Contributions to Mineralogy and Petrology, 143(5), 602-622, http://dx.doi.org/10.1007/s00410-002-0364-7.

Breiter K., Copjakova R. and Skoda R., 2010. The involvement of $\mathrm{F}, \mathrm{CO}_{2}$, and As in the alteration of $\mathrm{Zr}$-Th-REE-bearing accessory minerals in the Hora Svate Kateriny A-type granite, Czech Republic. Canadian Mineralogist, 47(6), 1375-1398, http://dx.doi.org/10.3749/ canmin.47.6.1375. 
Burns R.G., 1993. Mineralogical Applications of Crystal Field Theory, 2nd edn. Cambridge University Press, Cambridge, 576 pp.

Cappelletti G., Ardizzone S., Fermo P. and Gilardoni S., 2005. The influence of iron content on the promotion of the zircon structure and the optical properties of pink coral pigments. Journal of the European Ceramic Society, 25(6), 911-917, http://dx.doi.org/10.1016/j. jeurceramsoc.2004.04.023.

Chase A.B. and Osmer J.A., 1966. Growth and preferential doping of zircon and thorite. Journal of the Electrochemical Society, 113(2), 198-199, http://dx.doi.org/ $10.1149 / 1.2423904$

Chen T., Ai H., Yang M., Zheng S. and Liu Y., 2011. Brownish red zircon from Muling, China. Gems \& Gemology, 47(1), 36-41, http://dx.doi.org/10.5741/gems.47.1.36.

Condon D., McLean N., Schoene B., Bowring S., Parrish R. and Noble S., 2008. Synthetic U-Pb 'standard' solutions for ID-TIMS geochronology. Geochimica et Cosmochimica Acta, 72(12S), Goldschmidt Abstracts 2008-C, A175, http://dx.doi.org/10.1016/j.gca.2008.05.006.

Corfu F., 2004. U-Pb age, setting and tectonic significance of the anorthosite-mangerite-charnockite-granite suite, Lofoten-Vesteralen, Norway. Journal of Petrology, 45(9), 1799-1819, http://dx.doi.org/10.1093/petrology/egh034.

Couwenberg I., Binnemans K., De Leebeeck H. and GörllerWalrand C., 1998. Spectroscopic properties of the trivalent terbium ion in the huntite matrix $\mathrm{TbAl}_{3}\left(\mathrm{BO}_{3}\right)_{4}$. Journal of Alloys and Compounds, 274(1-2), 157-163, http://dx.doi.org/10.1016/s0925-8388(98)00549-0.

Del Nero G., Cappelletti G., Ardizzone S., Fermo P. and Gilardoni S., 2004. Yellow Pr-zircon pigments: The role of praseodymium and of the mineralizer. Journal of the European Ceramic Society, 24(14), 3603-3611, http://dx.doi.org/10.1016/j.jeurceramsoc.2004.01.003.

Demiray T., Nath D.K. and Hummel F.A., 1970. Zirconvanadium blue pigment. Journal of the American Ceramic Society, 53(1), 1-4, http://dx.doi.org/ 10.1111/j.1151-2916.1970.tb11987.x.

Dieke G.H. and Crosswhite H.M., 1963. The spectra of the doubly and triply ionized rare earths. Applied Optics, 2(7), 675-686, http://dx.doi.org/10.1364/ao.2.000675.

Dorais M.J. and Tubrett M., 2012. Detecting peritectic garnet in the peraluminous Cardigan pluton, New Hampshire. Journal of Petrology, 53(2), 299-324, http://dx.doi. org/10.1093/petrology/egr063.

Douglas J.G., Carò F. and Fischer C., 2008. Evidence of sandstone usage for sculpture during the Khmer Empire in Cambodia through petrographic analysis. Udaya, Journal of Khmer Studies, 9, 1-17.

Ewing R.C., 1994. The metamict state: 1993 - The centennial. Nuclear Instruments and Methods in Physics Research Section B: Beam Interactions with Materials and Atoms, 91(1-4), 22-29, http://dx.doi. org/10.1016/0168-583x(94)96186-7.
Ewing R.C., Meldrum A., Wang L., Weber W.J. and Corrales L.R., 2003. Radiation effects in zircon. Reviews in Mineralogy and Geochemistry, 53(1), 387-425, http://dx.doi.org/10.2113/0530387.

Faulkner M.J. and Shigley J.E., 1989. Zircon from the Harts Range, Northern Territory, Australia. Gems \& Gemology, 25(4), 207-215, http://dx.doi.org/10.5741/ gems.25.4.207.

Fielding P.E., 1970. The distribution of uranium, rare earths, and color centers in a crystal of natural zircon. American Mineralogist, 55(3-4), 428-440.

Gaft M., Panczer G., Reisfeld R. and Shinno I., 2000. Laser-induced luminescence of rare-earth elements in natural zircon. Journal of Alloys and Compounds, 300-301, 267-274, http://dx.doi.org/10.1016/ s0925-8388(99)00781-1.

Gastil R.G., DeLisle M. and Morgan J.R., 1967. Some effects of progressive metamorphism on zircons. Geological Society of America Bulletin, 78(7), 879-906, http://dx.doi.org/10.1130/0016-7606(1967)78\%5B879: seopmo\%5D2.0.co;2.

Gibbons A.D., Zahirovic S., Müller R.D., Whittaker J.M. and Yatheesh V., 2015. A tectonic model reconciling evidence for the collisions between India, Eurasia and intra-oceanic arcs of the central-eastern Tethys. Gondwana Research, 28(2), 451-492, http://dx.doi. org/10.1016/j.gr.2015.01.001.

Hanchar J.M. and van Westrenen W., 2007. Rare earth element behavior in zircon-melt systems. Elements, 3(1), 37-42, http://dx.doi.org/10.2113/gselements.3.1.37.

Hanchar J.M., Finch R.J., Hoskin P.W.O., Watson E.B., Cherniak D.J. and Mariano A.N., 2001. Rare earth elements in synthetic zircon: Part 1. Synthesis, and rare earth element and phosphorus doping. American Mineralogist, 86(5-6), 667-680, http://dx.doi.org/ 10.2138/am-2001-5-607.

Hay D.C. and Dempster T.J., 2009. Zircon behaviour during low-temperature metamorphism. Journal of Petrology, 50(4), 571-589, http://dx.doi.org/10.1093/petrology/ egp011.

Hejny C., Miletich R., Jasser A., Schouwink P., Crichton W. and Kahlenberg V., 2012. Second-order $P \overline{6} c 2-P 31 c$ transition and structural crystallography of the cyclosilicate benitoite, $\mathrm{BaTiSi}_{3} \mathrm{O}_{9}$, at high pressure. American Mineralogist, 97(10), 1749-1763, http://dx.doi.org/10.2138/am.2012.4175.

Hinton R.W. and Upton B.G.J., 1991. The chemistry of zircon: Variations within and between large crystals from syenite and alkali basalt xenoliths. Geochimica et Cosmochimica Acta, 55(11), 3287-3302, http://dx.doi. org/10.1016/0016-7037(91)90489-r.

Hoang N. and Flower M., 1998. Petrogenesis of Cenozoic basalts from Vietnam: Implication for origins of a 'diffuse igneous province'. Journal of Petrology, 39(3), 369-395, http://dx.doi.org/10.1093/petroj/39.3.369. 
Holland H.D. and Gottfried D., 1955. The effect of nuclear radiation on the structure of zircon. Acta Crystallographica, 8(6), 291-300, http://dx.doi. org/10.1107/s0365110x55000947.

Hoskin P.W.O. and Ireland T.R., 2000. Rare earth element chemistry of zircon and its use as a provenance indicator. Geology, 28(7), 627-630, http://dx.doi.org/ 10.1130/0091-7613(2000)28\%3C627:reecoz\%3E2.0.co;2.

Hoskin P.W.O. and Schaltegger U., 2003. The composition of zircon and igneous and metamorphic petrogenesis. Reviews in Mineralogy and Geochemistry, 53(1), 27-62, http://dx.doi.org/10.2113/0530027.

Hoskin P.W.O., Kinny P.D., Wyborn D. and Chappell B.W., 2000. Identifying accessory mineral saturation during differentiation in granitoid magmas: An integrated approach. Journal of Petrology, 41 (9), 1365-1396, http://dx.doi.org/10.1093/petrology/41.9.1365.

Huong L.T.-T., Vuong B.S., Thuyet N.T.M., Khoi N.N., Satitkune S., Wanthanachaisaeng B., Hofmeister W., Häger T. and Hauzenberger C., 2016. Geology, gemmological properties and preliminary heat treatment of gem-quality zircon from the Central Highlands of Vietnam. Journal of Gemmology, 35(4), 308-318, http://dx.doi.org/10.15506/JoG.2016.35.4.308.

Jochum K.P., Nohl U., Herwig K., Lammel E., Stoll B. and Hofmann A.W., 2005. GeoReM: A new geochemical database for reference materials and isotopic standards. Geostandards and Geoanalytical Research, 29(3), 333-338, http://dx.doi.org/10.1111/j.1751-908X.2005. tb00904.x.

Kar J.K., Stevens R. and Bowen C.R., 2004. Novel terbiumzircon yellow pigment. Journal of Materials Science, 39(18), 5755-5763, http://dx.doi.org/10.1023/b:jmsc. 0000040086.92465.50.

Kempe U., Trinkler M., Pöppl A. and Himcinschi C., 2016. Coloration of natural zircon. Canadian Mineralogist, 54(3), 635-660, http://dx.doi.org/10.3749/ canmin. 1500093 .

Klinger M., Kempe U., Pöpl A., Böttcher R. and Trinkler M., 2012. Paramagnetic hole centres in natural zircon and zircon coloration. European Journal of Mineralogy, 24(6), 1005-1016, http://dx.doi. org/10.1127/0935-1221/2012/0024-2236.

Koivula J.I. and Misiorowski E., Eds. 1986. Gem News: Undesirable color change in blue zircon. Gems \& Gemology, 22(3), 188-189.

Krogh T.E., 1973. A low-contamination method for hydrothermal decomposition of zircon and extraction of $\mathrm{U}$ and $\mathrm{Pb}$ for isotopic age determinations. Geochimica et Cosmochimica Acta, 37(3), 485-494, http://dx.doi. org/10.1016/0016-7037(73)90213-5.

Laithummanoon T. and Wongkokua W., 2013. Effect of heat treatment on color of natural zircon. Journal of King Mongkut's University of Technology North Bangkok, 23(2), 261-269.
Lenz C., Nasdala L., Talla D., Hauzenberger C., Seitz R. and Kolitsch U., 2015. Laser-induced REE ${ }^{3+}$ photoluminescence of selected accessory minerals An "advantageous artefact" in Raman spectroscopy. Chemical Geology, 415, 1-16, http://dx.doi. org/10.1016/j.chemgeo.2015.09.001.

Ma C. and Rossman G.R., 2005. Microanalysis of hafnian zircon. Microscopy and Microanalysis, 11 (S02), 1304-1305, http://dx.doi.org/10.1017/ s1431927605510730.

Malusà M.G., Carter A., Limoncelli M., Villa I.M. and Garzanti E., 2013. Bias in detrital zircon geochronology and thermochronometry. Chemical Geology, 359, 90-107, http://dx.doi.org/10.1016/j. chemgeo.2013.09.016.

McClure S.F., 2011. Lab Notes: Tenebrescent zircon. Gems \& Gemology, 47(4), 314-315.

Merlet C., 1994. An accurate computer correction program for quantitative electron probe microanalysis. Microchimica Acta, 114(1), 363-376, http://dx.doi. org/10.1007/bf01244563.

Murakami T., Chakoumakos B.C., Ewing R.C., Lumpkin G.R. and Weber W.J., 1991. Alpha-decay event damage in zircon. American Mineralogist, 76, 1510-1532.

Nasdala L., Irmer G. and Wolf D., 1995. The degree of metamictization in zircon: A Raman spectroscopic study. European Journal of Mineralogy, 7(3), 471-478, http://dx.doi.org/10.1127/ejm/7/3/0471.

Nasdala L., Wenzel M., Vavra G., Irmer G., Wenzel T. and Kober B., 2001. Metamictisation of natural zircon: Accumulation versus thermal annealing of radioactivity-induced damage. Contributions to Mineralogy and Petrology, 141(2), 125-144, http://dx.doi.org/10.1007/s004100000235.

Nasdala L., Lengauer C.L., Hanchar J.M., Kronz A., Wirth R., Blanc P., Kennedy A.K. and Seydoux-Guillaume A.-M., 2002. Annealing radiation damage and the recovery of cathodoluminescence. Chemical Geology, 191(1-3), 121-140, http://dx.doi.org/10.1016/ s0009-2541(02)00152-3.

Nasdala L., Zhang M., Kempe U., Panczer G., Gaft M., Andrut M. and Plötze M., 2003. Spectroscopic methods applied to zircon. Reviews in Mineralogy and Geochemistry, 53(1), 427-467, http://dx.doi. org/10.2113/0530427.

Nasdala L., Reiners P.W., Garver J.I., Kennedy A.K., Stern R.A., Balan E. and Wirth R., 2004. Incomplete retention of radiation damage in zircon from Sri Lanka. American Mineralogist, 89(1), 219-231, http://dx.doi. org/10.2138/am-2004-0126.

Niesert A., Hanrath M., Siggel A., Jansen M. and Langer K., 2002. Theoretical study of the polarized electronic absorption spectra of vanadium-doped zircon. Journal of Solid State Chemistry, 169(1), 6-12, http://dx.doi. org/10.1016/s0022-4596(02)00010-5. 
Paton C., Hellstrom J., Paul B., Woodhead J. and Hergt J., 2011. Iolite: Freeware for the visualisation and processing of mass spectrometric data. Journal of Analytical Atomic Spectrometry, 26(12), 2508-2518, http://dx.doi.org/10.1039/c1ja10172b.

Pearce N.J.G., Perkins W.T., Westgate J.A., Gorton M.P., Jackson S.E., Neal C.R. and Chenery S.P., 1997. A compilation of new and published major and trace element data for NIST SRM 610 and NIST SRM 612 glass reference materials. Geostandards and Geoanalytical Research, 21(1), 115-144, http://dx.doi.org/ 10.1111/j.1751-908X.1997.tb00538.x.

Pérez-Soba C., Villaseca C., Del Tanago J.G. and Nasdala L., 2007. The composition of zircon in the peraluminous Hercynian granites of the Spanish Central System batholith. Canadian Mineralogist, 45(3), 509-527, http://dx.doi.org/10.2113/gscanmin.45.3.509.

Pyon K.-R., Han K.-S. and Lee B.-H., 2011. Formation and color properties of vanadium doped $\mathrm{ZrSiO}_{4}$ ceramic pigments. Journal of Ceramic Processing Research, 12(3), 279-288.

Rangin C., Huchon P., Le Pichon X., Bellon H., Lepvrier C., Roques D., Hoe N.D. and Quynh P.V., 1995. Cenozoic deformation of central and south Vietnam. Tectonophysics, 251(1-4), 179-196, http://dx.doi. org/10.1016/0040-1951(95)00006-2.

Renfro N.D., 2016. Reversible color modification of blue zircon by long-wave ultraviolet radiation. Gems \& Gemology, 52(3), 246-251, http://dx.doi.org/10.5741/ gems.52.3.246.

Richman I., Kisliuk P. and Wong E.Y., 1967. Absorption spectrum of $\mathrm{U}^{4+}$ in zircon $\left(\mathrm{ZrSiO}_{4}\right)$. Physical Review, 155(2), 262-267, http://dx.doi.org/10.1103/PhysRev. 155.262 .

Roskin G., 2003. Cambodian blue zircon. www.jckonline. com/magazine-article/cambodian-blue-zircon, 1 November, accessed 14 April 2018.

Rossman G.R., 1981. Color in gems: The new technologies. Gems \& Gemology, 17(2), 60-71, http://dx.doi.org/ 10.5741/gems.17.2.60.

Russo d.M. and Punzo I., 2004. I minerali del SommaVesuvio. Associazione Micro-mineralogica Italiana, Cremona, Italy, 320 pp.

Sahama T.G., 1981. Growth structure in Ceylon zircon. Bulletin de Minéralogie, 104, 89-94.

Satitkune S., Wanthanachaisaeng B., Won-in K., Wongkokau W., Chantararat P., Leelawattanasuk T. and Wathanakul P., 2013. Heat treatment of zircon samples from Kanchanaburi, Thailand and Ratanakiri, Cambodia. 33rd International Gemmological Conference, Hanoi, Vietnam, 12-16 October, 158-160.

Saurin E., 1957. Some gem occurrences in Cambodia. Rocks \& Minerals, 32(7-8), 397-398, http://dx.doi.org/10.108 $0 / 00357529.1957 .11766953$.

Schärer U., 1984. The effect of initial ${ }^{230} \mathrm{Th}$ disequilibrium on young U-Pb ages: The Makalu case, Himalaya.
Earth and Planetary Science Letters, 67 (2), 191-204, http://dx.doi.org/10.1016/0012-821x(84)90114-6.

Shigley J.E., Laurs B.M., Janse A.J.A., Elen S. and Dirlam D.M., 2010. Gem localities of the 2000s. Gems \& Gemology, 46(3), 188-216, http://dx.doi.org/10.5741/ gems.46.3.188.

Siriaucharanon W., Lomthong P. and Wanthanachaisaeng B., 2017. Heat treatment of zircon from Tanzania and Cambodia. GIT Gems \& Jewelry, No. 20, 29.

Škoda R., Plášil J., Jonsson E., Čopjaková R., Langhof J. and Galiová M.V., 2015. Redefinition of thalénite-(Y) and discreditation of fluorthalénite-(Y): A re-investigation of type material from the Österby pegmatite, Dalarna, Sweden, and from additional localities. Mineralogical Magazine, 79(4), 965-983, http://dx.doi.org/10.1180/ minmag.2015.079.4.07.

Smith M.H. and Balmer W.A., 2009. Gem News International: Zircon mining in Cambodia. Gems \& Gemology, 45(2), 152-153.

Stacey J.S. and Kramers J.D., 1975. Approximation of terrestrial lead isotope evolution by a two-stage model. Earth and Planetary Science Letters, 26(2), 207-221, http://dx.doi.org/10.1016/0012-821x(75)90088-6.

Stiebler M., Steudtner C. and Kemmler-Sack S., 1992. Praseodymium zircon yellow. Physica Status Solidi (a), 132(2), 495-500, http://dx.doi.org/10.1002/ pssa.2211320225.

Sutherland F.L., Bosshart G., Fanning C.M., Hoskin P.W.O. and Coenraads R.R., 2002. Sapphire crystallization, age and origin, Ban Huai Sai, Laos: Age based on zircon inclusions. Journal of Asian Earth Sciences, 20(7), 841-849, http://dx.doi.org/10.1016/ s1367-9120(01)00067-0.

Sutherland F., Piilonen P.C., Zaw K., Meffre S. and Thompson J., 2015. Sapphire within zircon-rich gem deposits, Bo Loei, Ratanakiri Province, Cambodia: Trace elements, inclusions, $\mathrm{U}-\mathrm{Pb}$ dating and genesis. Australian Journal of Earth Sciences, 62(6), 761-773.

Sutherland L., Graham I., Yaxley G., Armstrong R., Giuliani G., Hoskin P., Nechaev V. and Woodhead J., 2016. Major zircon megacryst suites of the Indo-Pacific lithospheric margin (ZIP) and their petrogenetic and regional implications. Mineralogy and Petrology, $110(2-3), 399-420$, http://dx.doi.org/10.1007/ s00710-015-0421-3.

Suthiyuth R., 2014. Lab Notes: Tenebrescent zircon. Gems \& Gemology, 50(2), 156-157.

Thongcham K., Sahavat S. and Wongkokua W., 2010. Effects of annealing to colour of zircon. Pro-Gem-Geo-Mat 2010: 5th International Workshop on Provenance and Properties of Gems and Geo-Materials, Hanoi, Vietnam, 17-24 October, 111-113.

United Nations, 1993. Atlas of Mineral Resources of the ESCAP Region. Vol. 10, Cambodia. United Nations Economic and Social Commission for Asia and the Pacific, New York, New York, USA, 87 pp. 
Váczi T., 2014. A new, simple approximation for the deconvolution of instrumental broadening in spectroscopic band profiles. Applied Spectroscopy, 68(11), 1274-1278, http://dx.doi.org/10.1366/13-07275.

Van Lichtervelde M., Melcher F. and Wirth R., 2009. Magmatic vs. hydrothermal origins for zircon associated with tantalum mineralization in the Tanco pegmatite, Manitoba, Canada. American Mineralogist, 94(4), 439-450, http://dx.doi.org/10.2138/am.2009.2952.

Van Westrenen W., Frank M.R., Hanchar J.M., Fei Y., Finch R.J. and Zha C.-S., 2004. In situ determination of the compressibility of synthetic pure zircon $\left(\mathrm{ZrSiO}_{4}\right)$ and the onset of the zircon-reidite phase transition. American Mineralogist, 89(1), 197-203, http://dx.doi. org/10.2138/am-2004-0123.

Vance E.R. and Mackey D.J., 1974. Optical study of $\mathrm{U}^{5+}$ in zircon. Journal of Physics C: Solid State Physics, 7(10), 1898-1908, http://dx.doi.org/10.1088/ 0022-3719/7/10/017.

Vaz J.E. and Senftle F.E., 1971. Thermoluminescence study of the natural radiation damage in zircon. Journal of Geophysical Research, 76, 2038-2050, http://dx.doi. org/10.1029/JB076i008p02038.

Wanthanachaisaeng B., Bunnag N., Sutthirat C., Ounorn P., Phattarawarin P. and Pisutha-Arnond V., 2010.

Determination of heat treated zircon by FTIR spectrophotometer. Pro-Gem-Geo-Mat 2010: 5th International Workshop on Provenance and Properties of Gems and Geo-Materials, Hanoi, Vietnam, 17-20 October, 97-99.

Wanthanachaisaeng B., Bunnag N., Satitkune S., Ounorn P., Sutthirat C. and Pisutha-Arnond V., 2014. Influence of irradiation and heating on the Ratanakiri zircon structure. 4th International Gem and Jewelry Conference (GIT 2014), Chiang Mai, Thailand, 8-12 December, 101-103.
Watson E.B., 2007. Zircon in technology and everyday life. Elements, 3(1), 52.

Wiedenbeck M., Hanchar J.M., Peck W.H., Sylvester P., Valley J., Whitehouse M., Kronz A., Morishita Y., Nasdala L., Fiebig J., Franchi I., Girard J.P., Greenwood R.C., Hinton R., Kita N., Mason P.R.D., Norman M., Ogasawara M., Piccoli P.M., Rhede D., Satoh H., Schulz-Dobrick B., Skår O., Spicuzza M.J., Terada K., Tindle A., Togashi S., Vennemann T., Xie Q. and Zheng Y.F., 2004. Further characterisation of the 91500 zircon crystal. Geostandards and Geoanalytical Research, 28(1), 9-39, http://dx.doi.org/10.1111/j.1751908X.2004.tb01041.x.

Xu X.-S., Zhang M., Zhu K.-Y., Chen X.-M. and He Z.-Y., 2012. Reverse age zonation of zircon formed by metamictisation and hydrothermal fluid leaching. Lithos, 150, 256-267, http://dx.doi.org/10.1016/j.lithos.2011.12.014.

Zamyatin D.A., Shchapova Y.V., Votyakov S.L., Nasdala L. and Lenz C., 2017. Alteration and chemical U-Th-total $\mathrm{Pb}$ dating of heterogeneous high-uranium zircon from a pegmatite from the Aduiskii Massif, Middle Urals, Russia. Mineralogy and Petrology, 111 (4), 475-497, http://dx.doi.org/10.1007/s00710-017-0513-3.

Zhang M., Salje E.K.H., Farnan I., Graeme-Barber A., Daniel P., Ewing R.C., Clark A.M. and Leroux H., 2000. Metamictization of zircon: Raman spectroscopic study. Journal of Physics: Condensed Matter, 12(8), 1915-1925, http://dx.doi.org/10.1088/0953-8984/12/8/333.

Zhang M., Salje E.K.H. and Ewing R.C., 2003. Oxidation state of uranium in metamict and annealed zircon: Near-infrared spectroscopic quantitative analysis. Journal of Physics: Condensed Matter, 15(20), 3445-3470, http://dx.doi.org/ 10.1088/0953-8984/15/20/307.

\section{The Authors}

\section{Manuela Zeug, Prof. Dr Lutz Nasdala and Prof. Dr Manfred Wildner \\ Institut für Mineralogie und Kristallographie, University of Vienna, Althanstraße 14, 1090 Vienna, Austria. Email: manuela.zeug@univie.ac.at}

\section{Dr Walter A. Balmer}

SSEF Swiss Gemmological Institute, Aeschengraben 26, 4051 Basel, Switzerland; and Department of Geology, Faculty of Science, Chulalongkorn University, Bangkok 10330, Thailand

\section{Dr Fernando Corfu}

Department of Geosciences and CEED (Centre for Earth Evolution and Dynamics), University of Oslo, P.O. Box 1047, Blindern, 0316 Oslo, Norway

\section{Dr Bhuwadol Wanthanachaisaeng}

Faculty of Science, Srinakharinwirot University, 114 Sukhumvit 23, Bangkok 10110, Thailand; and Faculty of Gems, Burapha University, Chanthaburi 22170, Thailand

\section{Acknowledgements}

Authors WAB, LN and BW are deeply indebted to Mr Votha Un (deceased) of Pailin, Cambodia, who in 2008 and 2012 guided field trips to several zircon deposits in Ratanakiri Province. Ralf Grunert, Mark H. Smith and Astrid Wittwer kindly provided photographs. We thank Dr George R. Rossman and Dr John M. Hanchar for the loan of synthetic blue $\mathrm{ZrSiO}_{4}$ crystals, and Dr Dominik Talla for providing REE-doped $\mathrm{ZrSiO}_{4}$ crystals. Thanks also are due to Andreas Wagner for sample preparation. We are indebted to Dr Radek Škoda, Wilfredo G. Diegor, Christian Petautschnig, Dr Martin Ende and Dr Gerald Giester for experimental help, and to Wolfgang Zirbs for technical assistance. We thank Dr Klaus Krambrock for helpful discussions and constructive comments. Author LN acknowledges support of the 2012 field trip to Ratanakiri by ASEA-Uninet. Author BW acknowledges support by the Gem and Jewelry Institute of Thailand (Public Organisation). 